\title{
A study of the influence of tropospheric subsidence on spring and summer surface ozone concentrations at the JRC Ispra station in northern Italy
}

\author{
Pavlos Kalabokas $^{1}$, Niels Roland Jensen ${ }^{2}$, Mauro Roveri ${ }^{3}$, Jens Hjorth ${ }^{2,4}$, Maxim Eremenko ${ }^{5}$, Juan Cuesta ${ }^{5}$, \\ Gaëlle Dufour $^{5}$, Gilles Foret ${ }^{5}$, and Matthias Beekmann ${ }^{5}$ \\ ${ }^{1}$ Academy of Athens, Research Center for Atmospheric Physics and Climatology, Athens, Greece \\ ${ }^{2}$ European Commission, Joint Research Centre (JRC), Directorate for Energy, Transport and Climate, \\ Air and Climate Unit, 21027 Ispra (VA), Italy \\ ${ }^{3}$ European Commission, Joint Research Centre (JRC), Directorate for Nuclear Safety and Security, 21027 Ispra (VA), Italy \\ ${ }^{4}$ Department of Environmental Science, iCLIMATE, Aarhus University, Frederiksborgvej 399, 4000 Roskilde, Denmark \\ ${ }^{5}$ Laboratoire Interuniversitaire des Systèmes Atmosphériques (LISA), UMR 7583, CNRS, Université Paris-Est-Créteil, \\ Université de Paris, Institut Pierre Simon Laplace, Créteil, France
}

Correspondence: Pavlos Kalabokas (pkalabokas@academyofathens.gr)

Received: 8 May 2019 - Discussion started: 16 May 2019

Revised: 14 November 2019 - Accepted: 4 December 2019 - Published: 18 February 2020

\begin{abstract}
The influence of tropospheric ozone on the surface ozone concentrations is investigated at the monitoring station of JRC Ispra, based on 10 years of measurements (2006-2015) of surface ozone data. In situ hourly measurements of ozone and other air pollutants, meteorological parameters, and weekly averaged ${ }^{7} \mathrm{Be}$ (as an indicator of upper-tropospheric-stratospheric influence) and ${ }^{210} \mathrm{~Pb}$ measurements (as an indicator of boundary layer influence) have been used for the analysis. In addition, IASI + GOME-2 and IASI ozone satellite data have also been used. It is observed that frequently ${ }^{7} \mathrm{Be}$ and ozone weekly peaks coincide, which might be explained by the impact of deep atmospheric subsidence on surface ozone, particularly during late spring and early summer. Based on this observation, a detailed analysis of selected ${ }^{7} \mathrm{Be}$ and ozone episodes occurring during that period of the year has been performed in order to further elucidate the mechanisms of tropospheric influence on the surface pollutant concentrations. For the analysis, composite NOAA/ESRL reanalysis synoptic meteorological charts in the troposphere have been used as well as IASI satellite ozone measurements and NOAA HYSPLIT back trajectories. The JRC station hourly measurements during subsidence episodes show very low values of local pollution parameters (e.g., $\mathrm{NO}_{x},{ }^{222} \mathrm{Rn}$, nephelometer data, $\mathrm{PM}_{10}$ ), close
\end{abstract}

to zero. Conversely, during these periods ozone levels usually reach values around 45-60 ppb during the afternoon hours but also show significantly higher values than the average during the night and morning hours, which is a sign of direct tropospheric influence on the surface ozone concentrations.

\section{Introduction}

It has been reported that tropospheric ozone levels as well as surface ozone concentrations have increased significantly during the last couple of centuries (Volz and Kley, 1988; Forster et al., 2007; Monks et al., 2015; Gaudel et al., 2018). Ozone is an important greenhouse gas and can cause adverse effects on human health and also have negative impacts on vegetation and materials (Ito et al., 2005; Van Dingenen et al., 2009; Hollaway et al., 2012). Tropospheric ozone is mainly produced in the troposphere through photochemical reactions of precursor pollutants but it does also originate from stratospheric intrusions (Volz and Kley, 1988; Staehelin et al., 1994). On average, the tropospheric ozone originating from the stratosphere is about $10 \%$ on a global scale (Monks et al., 2015). The surface ozone concentrations depend on photochemistry and transport within the boundary layer as 
well as tropospheric entrainment, which might also be associated with deep tropospheric subsidence, especially over the Mediterranean during summer where, in general, high ozone levels are observed (Kalabokas et al., 2000; Kouvarakis et al., 2000; Lelieveld et al., 2002, 2009; Zerefos et al., 2002, 2007, 2008, 2013, 2015; Gerasopoulos et al., 2005; Velchev et al., 2011; Richards et al., 2013; Cooper et al., 2014; Safieddine et al., 2014).

The influence of intercontinental ozone transport on surface ozone concentrations is considered a critical issue regarding ozone pollution control (UNESCE, 2010) and this issue has been extensively studied, especially in the USA where many studies have shown that tropospheric transport and entrainment of ozone from the free troposphere to the boundary layer has an important impact on surface ozone-mixing ratios (Cooper et al., 2011, 2012; Parrish et al., 2013, 2014; Langford et al., 2015). Also, anticyclonic synoptic conditions are normally linked to tropospheric subsidence, which is considered to be an important source of high ozone concentrations over the eastern Mediterranean. During the summer period, the Mediterranean area is under the influence of the descending branch of the Hadley circulation (Lelieveld, 2009) in combination with the impact of the Indian monsoon, inducing a Rossby wave that through the interaction with the midlatitude westerlies produces adiabatic descent in the area (Rodwell and Hoskins, 1996, 2001; Tyrlis et al., 2013). In the eastern Mediterranean strong deep subsidence throughout the troposphere to the boundary layer, which seems to be a quite frequent phenomenon, has been documented based on the analysis of MOZAIC vertical ozone profiles as well as surface ozone and satellite measurements (Kalabokas et al., 2007, 2008, 2013, 2015; Eremenko et al., 2008; Foret et al., 2009; Liu et al., 2009; Doche et al., 2014; Gaudel et al., 2018). In addition, large-scale atmospheric modeling simulations ( $\mathrm{Li}$ et al., 2001; Richards et al., 2013; Zanis et al., 2014; Safieddine et al., 2014; Tyrlis et al., 2014; Akritidis et al., 2016; Cristofanelli et al., 2018) show the importance of the vertical ozone transport over the Mediterranean basin, especially in its eastern side. Also, sea-breeze circulation appears to have a particularly strong influence on ozone formation in the western Mediterranean, because it favors accumulation of ozone in recirculated polluted air masses (Millan et al., 1997, 2000; Castell et al., 2008). The atmospheric processes controlling ozone levels over the western and central Mediterranean need further studying, especially for what concerns the springtime months. It has been reported that surface background ozone levels in the western and central Mediterranean show a maximum in spring (April-May), while at the eastern Mediterranean stations a later ozone maximum appears in July-August (Kalabokas et al., 2008; Zanis et al., 2014). Also, it has been recently reported that high springtime ozone concentrations are detected over a large geographical area for several days under specific synoptic conditions, which could be explained by the impacts of tropospheric subsidence (Kal- abokas et al., 2017). Apart from tropospheric subsidence influencing near-surface ozone concentrations, it has to also be mentioned that there are climatological and case studies of stratospheric intrusions affecting near-surface ozone concentrations for the Mediterranean region (Kentarchos et al., 1998; Cristofanelli et al., 2006; Gerasopoulos et al., 2006; Akritidis et al., 2012).

Atmospheric radionuclides are useful for studies of tropospheric subsidence and transport, in particular terrigenous ${ }^{210} \mathrm{~Pb}$ and cosmogenic ${ }^{7} \mathrm{Be}$, which are natural radionuclides that are helpful in understanding the roles of transport and/or scavenging in controlling the behavior of radiatively active trace gases and aerosol (WMO-GAW, 2004; Feichter et al., 1991; Balkanski et al., 1993; Koch et al., 1996; Graustein and Turekian, 1996; Arimoto et al., 1999; Gerasopoulos et al., 2001; Zanis et al., 2003; Liu et al., 2004; Leppanen et al., 2010; Pham et al., 2011; Garcia et al., 2012; Jiwen et al., 2013; Cuevas et al., 2013; Ioannidou et al., 2014; Brattich et al., 2017). Due to their different origins, the investigation of ${ }^{210} \mathrm{~Pb}$ and ${ }^{7} \mathrm{Be}$ activities can be simultaneously useful for studies of atmospheric transport of pollutants, especially in the particle phase (Koch et al., 1996). ${ }^{210} \mathrm{~Pb}$ has a half-life of about 22 years. It originates from the decomposition of ${ }^{222} \mathrm{Rn}$, which has a half-life of $3.8 \mathrm{~d}$ and it is a decomposition product of ${ }^{226} \mathrm{Ra}$ originating from the ground (Baskaran, 2011). ${ }^{7} \mathrm{Be}$ has a cosmogenic origin and it is formed mostly by the decomposition of the atoms of carbon, nitrogen and oxygen present in the atmosphere by incident gamma radiation. It has a half-life of 53.3 d (Masarik and Beer, 1999). Its production rate increases with altitude and saturates at about $15 \mathrm{~km}$ height (Usokin and Kovaltsov, 2008). Most of ${ }^{7} \mathrm{Be}$ is produced in the stratosphere and about one-third in the troposphere, especially in its upper part (O'Brien, 1979). After their formation, ${ }^{7} \mathrm{Be}$ atoms are mostly attached to atmospheric particles and so their atmospheric concentrations are greatly influenced by transport and deposition processes of particles (Jaenicke, 1988; Feely et al., 1989; Papastefanou and Ioannidou, 1995; Koch et al., 1996; Bourcier et al., 2011; Duenas et al., 2011; Lozano et al., 2012; Steinmann et al., 2013; Hernández-Ceballos et al., 2016).

On average, the ${ }^{7} \mathrm{Be}$ concentrations in the upper troposphere are about $25 \%$ of the lower stratospheric concentrations (about $160 \mathrm{mBq} \mathrm{m}^{-3}$ ) at northern midlatitudes while ${ }^{7} \mathrm{Be}$ concentrations close to the ground are generally below $5 \mathrm{mBq} \mathrm{m}^{-3}$ (Reiter et al., 1983; Dutkiewicz and Husain, 1985; Brost et al., 1991; Gaggeler, 1995). Thus, air masses originating from the upper troposphere or stratosphere usually contain high ${ }^{7} \mathrm{Be}$ concentrations, and the intrusions of stratospheric air mass into the troposphere are the main processes transferring ${ }^{7} \mathrm{Be}$ to the earth's surface through dry or wet deposition. Therefore, ${ }^{7} \mathrm{Be}$ serves as a tracer for lowerstratospheric and upper-tropospheric air masses arriving to the ground (Lee et al., 2007; Papastefanou et al., 2012). Due to the exchange and removal processes in the atmosphere, the ${ }^{7} \mathrm{Be}$ concentration in air at ground level varies strongly with 
the season while ${ }^{7} \mathrm{Be}$ production rates in the atmosphere remain relatively constant (Durana et al., 1996; Masarik and Beer, 1999). In general, ${ }^{7} \mathrm{Be}$ surface concentrations show a maximum in late summer (Reiter et al., 1983; Feely et al., 1989; Bourcier et al., 2011; Hernández-Ceballos et al., 2016).

The investigation of the atmospheric processes controlling the frequently observed springtime ozone maximum over parts of the European continent including the western Mediterranean is an interesting research issue as photochemical ozone production and tropospheric transport, including stratospheric influence, might be involved (Beekmann et al., 1994; Monks, 2000). It has been previously reported that high surface ozone concentrations, lasting several days, have been observed over large geographical areas at the same time (Kalabokas et al., 2017). It has also been shown that the observed regional springtime ozone episodes are usually associated with specific synoptic meteorological patterns, which have great similarities to those observed during the summertime ozone episodes over the eastern Mediterranean and are linked to large-scale subsidence (Kalabokas et al., 2013, 2015; Doche et al., 2014).

In the previous study (Kalabokas et al., 2017) some tropospheric mechanisms related to regional ozone episodes especially linked with large-scale subsidence were examined. In this paper a more detailed analysis of the suggested mechanisms was performed, based on the measurements of ${ }^{7} \mathrm{Be}$, ${ }^{210} \mathrm{~Pb}$ and a large variety of meteorological and air pollution parameters collected at the JRC Ispra station, which is considered to be one of the most well-equipped measuring sites in Europe. The present study focuses on the influence of tropospheric subsidence on surface ozone concentrations, especially during spring and summer months over the western Mediterranean area. It is based on the analysis of 10 years of ozone and other air pollution measurement data (2006-2015) as well as measurements of natural radionuclide tracers at surface level, which can be used as tracers of transport and photochemical and removal processes. These data are collected at the JRC Ispra site, located in the pre-Alpine area in northern Italy but also located relatively close to the western Mediterranean. In addition, we used meteorological maps, back trajectories and IASI satellite ozone data for a better understanding of the relative importance of the contributions of the different sources of ozone, especially the role of the vertical transport in the troposphere. To our knowledge, a similar analysis of such multiparameter long-term measurements has not yet been performed so far for this area.

\section{Experimental}

\subsection{Site description}

The JRC Ispra station $\left(45.807^{\circ} \mathrm{N}, 8.631^{\circ} \mathrm{E}, 223 \mathrm{~m}\right.$ a.s.l. $)$ is located in a valley in the pre-Alpine area of northern Italy. A general meteorological characteristic of the area is that low winds usually prevail with occasional northerly Foehn events (Mira-Salama et al., 2008). More details about the site can be found in Putaud et al., 2017.

\subsection{Instrumentations and measurements at JRC Ispra site}

The information on the instrumentation used for this investigation is presented in Table 1.

Regarding the meteorological measurements, a WXT510 weather transmitter from Vaisala simultaneously recorded six meteorological parameters, temperature, pressure, relative humidity, precipitation, wind speed and wind direction, from the top of an about $10 \mathrm{~m}$ high mast. Humidity (ppmV) was calculated from relative humidity $(\mathrm{RH})$, temperature and atmospheric pressure, which was useful for the data analysis as an air mass reaching the surface by transport from higher altitudes will typically be relatively dry and entrainment of air from the free troposphere is thus normally associated with a drop in humidity mixing ratio as well as specific humidity.

\subsection{Meteorological maps and back trajectories}

Composite NOAA/ESRL reanalysis meteorological charts of various meteorological parameters for selected ozone episodes and at the atmospheric pressure levels of 850,700 and $500 \mathrm{hPa}$ have been produced with a horizontal resolution of $2.5^{\circ} \times 2.5^{\circ}$ (Kalnay et al., 1996). Due to space limitations, mostly the $700 \mathrm{hPa}$ charts, representative for the free troposphere, are presented. In addition, $6 \mathrm{~d}$ NOAA/HYSPLIT back trajectories for selected high-ozone days for air masses arriving at the JRC Ispra site at various end points have been plotted, using the GDAS meteorological data (Draxler and Rolph, 2015).

\subsection{IASI and IASI + GOME-2 satellite ozone measurements}

Progress in satellite observations of tropospheric ozone has been made during the last decade (e.g., Fishman et al., 2003; Liu et al., 2005; Coheur et al., 2005; Worden et al., 2007; Eremenko et al., 2008, Cuesta et al., 2013). This progress combined with its spatial coverage and horizontal resolution make it possible to use such observations to complement in situ observations and to support the analysis of ground measurements as well as modeling simulations. In this study, we use ozone satellite observations derived from the IASI infrared instruments and from the multispectral synergism of IASI and GOME-2 in the ultraviolet range, for enhancing sensitivity to ozone closer to the surface. The first IASI instrument (Clerbaux et al., 2009) was launched on board the MetOp-A platform on 19 October 2006. It is a Fourier transform spectrometer operating at nadir in the thermal infrared between 645 and $2760 \mathrm{~cm}^{-1}$ with an apodized spectral resolution of $0.5 \mathrm{~cm}^{-1}$. IASI monitors atmospheric composi- 
Table 1. Instruments and measurements at the JRC Ispra site.

\begin{tabular}{|c|c|c|c|c|c|}
\hline Variable & Instrument & Technique & Unit & Resolution & Reference \\
\hline Ozone & Thermo 49 & UV & $\mathrm{ppb}$ & $\begin{array}{l}\text { Hourly and } \\
6 \text { h daily } \\
\text { average }\end{array}$ & Putaud et al. (2017) \\
\hline${ }^{7} \mathrm{Be},{ }^{210} \mathrm{~Pb}$ & $\begin{array}{l}\text { GEM series } \\
\text { EG\&G Ortec }\end{array}$ & $\begin{array}{l}\text { Filter sampling, } \\
\text { HpGe coaxial } \\
\text { detectors }\end{array}$ & $\mu \mathrm{Bqm}^{-3}$ & $\begin{array}{l}\text { Weekly } \\
\text { average }\end{array}$ & Jensen et al. (2017) \\
\hline${ }^{222} \mathrm{Rn}$ & $\begin{array}{l}\text { ANSTO } \\
\text { (custom build) }\end{array}$ & $\begin{array}{l}\text { Filter sampling, } \\
\text { ANSTO detector }\end{array}$ & $\mu \mathrm{Bqm}^{-3}$ & $\begin{array}{l}\text { Hourly } \\
\text { average }\end{array}$ & $\begin{array}{l}\text { Zahorowski et al. (2004) } \\
\text { Putaud et al. (2017) }\end{array}$ \\
\hline $\begin{array}{l}\mathrm{NO}_{x} \\
\left(\mathrm{NO}, \mathrm{NO}_{2}\right)\end{array}$ & Thermo 42/42iTL & Chemiluminesc. & $\mathrm{ppb}$ & $\begin{array}{l}\text { Hourly } \\
\text { average }\end{array}$ & $\begin{array}{l}\text { Villena et al. (2012) } \\
\text { Putaud et al. (2017) }\end{array}$ \\
\hline $\begin{array}{l}\text { Particle } \\
\text { light } \\
\text { scattering }\end{array}$ & $\begin{array}{l}\text { Integrating } \\
\text { nephelometer } \\
\text { TSI } 3563\end{array}$ & $\begin{array}{l}\text { Light- } \\
\text { integration }\end{array}$ & $\mathrm{km}^{-1}$ & $\begin{array}{l}\text { Hourly } \\
\text { average }\end{array}$ & Putaud et al. (2017) \\
\hline $\mathrm{PM}_{10}$ & FDMS TEOM & TEOM & $\mu \mathrm{g} \mathrm{m}^{-3}$ & $\begin{array}{l}\text { Hourly } \\
\text { average }\end{array}$ & Putaud et al. (2017) \\
\hline $\begin{array}{l}\text { Relative } \\
\text { Humidity* }\end{array}$ & WXT510 & $\begin{array}{l}\text { Capacitive } \\
\text { Thin-film } \\
\text { sensor }\end{array}$ & ppm & $\begin{array}{l}\text { Hourly } \\
\text { and } 6 \mathrm{~h} \\
\text { average }\end{array}$ & Putaud et al. (2017) \\
\hline
\end{tabular}

* Other meteorological variables measured include temperature, pressure, precipitation, wind speed and wind direction (Putaud et al., 2017).

tion twice a day at any (cloud-free) location at high resolution with its swath width of $2200 \mathrm{~km}$ and its field of view composed of a 2 pixel $\times 2$ pixel matrix with a diameter at nadir of $12 \mathrm{~km}$ each (e.g., Boynard et al., 2009; George et al., 2009; Clarisse et al., 2011; Coman et al., 2012). As in Doche et al. (2014), IASI ozone concentrations retrieved at 3 and $10 \mathrm{~km}$ height are used for our analysis as being representative of the lower and upper troposphere, respectively. The maximum of sensitivity of IASI retrievals ranges between 3 and $5 \mathrm{~km}$ in the lower troposphere and 9 and $12 \mathrm{~km}$ in the upper troposphere. Several studies show that the ozone concentrations retrieved from IASI in the lower and upper troposphere are mainly uncorrelated (Dufour et al., 2010, 2012, 2015). We use the vertical profiles retrieved from IASI to calculate the longitudinal transect for different latitudes. Vertical profiles within $1^{\circ}$ in latitude and $0.5^{\circ}$ in longitude are averaged in the transect calculation.

The satellite multispectral approach used here is called IASI+GOME-2 (Cuesta et al., 2013). It is based on the joint and simultaneous use of both GOME-2 and IASI measurements for deriving a unique ozone profile for each pair of spectra. It is designed for observing the lowermost tropospheric ozone located below $3 \mathrm{~km}$ of altitude (with typically a peak of maximum sensitivity down to $2 \mathrm{~km}$ of altitude), which is not directly observed with single-band retrievals. Like IASI, GOME-2 is only on board the MetOp satellite series and offers global coverage every day (for MetOp-A around 09:30 local time) with a swath width similar to that of IASI and a ground resolution moderately coarser than that of IASI (pixels of $80 \mathrm{~km} \times 40 \mathrm{~km}$ for GOME-2). As described in detail by Cuesta et al. (2013), co-located IR and UV spectra are jointly fitted to retrieve a single vertical profile of ozone for each pixel at the IASI horizontal resolution. The UV measurements from the closest GOME-2 pixel (without averaging) are used for each IASI pixel. As for IASI-only retrievals, a priori ozone profiles representative of tropical, midlatitude and polar conditions are calculated by averaging the climatological ozone profiles from McPeters et al. (2007) over the 20-30, 30-60 and 60-90 $\mathrm{N}$ latitude bands. The selection of the a priori profiles used during the retrieval is based on the tropopause heights (determined by the temperature vertical profile for each IASI pixel) above $14 \mathrm{~km}$, between 14 and $9 \mathrm{~km}$, and below $9 \mathrm{~km}$, respectively. IASI + GOME-2 retrievals are routinely produced at the global scale by the French data center AERIS and they are publicly available (https://iasi.aeris-data.fr/O3_IAGO2/, last access: 15 May 2019).

\section{Results and discussion}

\subsection{Seasonal variation in $\mathrm{O}_{3}$ concentrations, ${ }^{7} \mathrm{Be}$ concentrations and the ${ }^{7} \mathrm{Be} /{ }^{210} \mathrm{~Pb}$ ratio}

For the investigation of entrainment episodes and based on information presented in the introduction, plots of weekly averages of ozone vs. ${ }^{7} \mathrm{Be}$ concentrations and that of ozone 
(a)

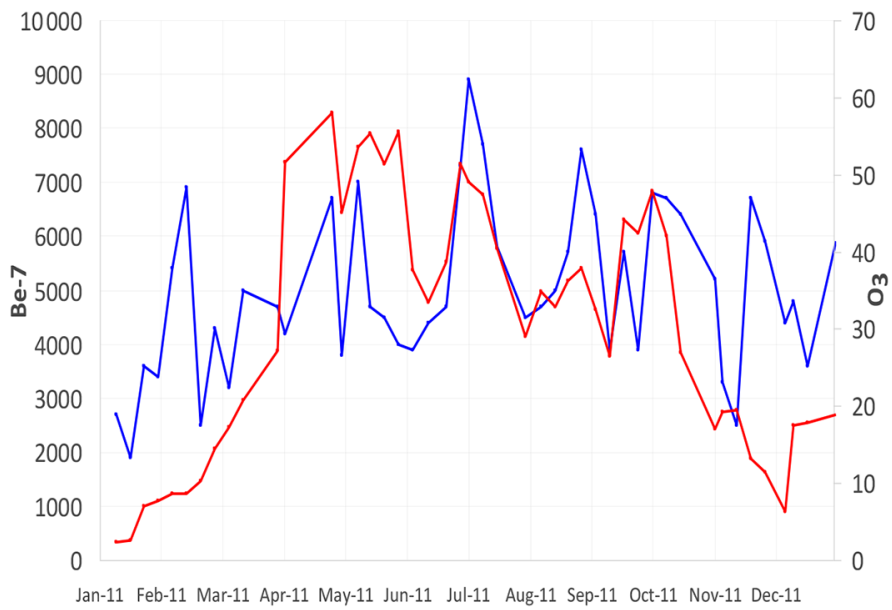

$-\mu B q \mathrm{~m} 3 \mathrm{-}-0312-18$ (b)

70

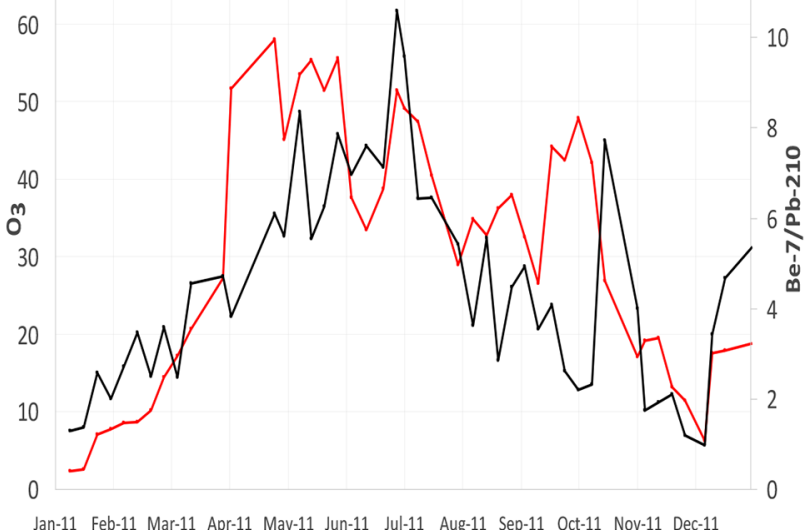

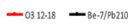

(c)

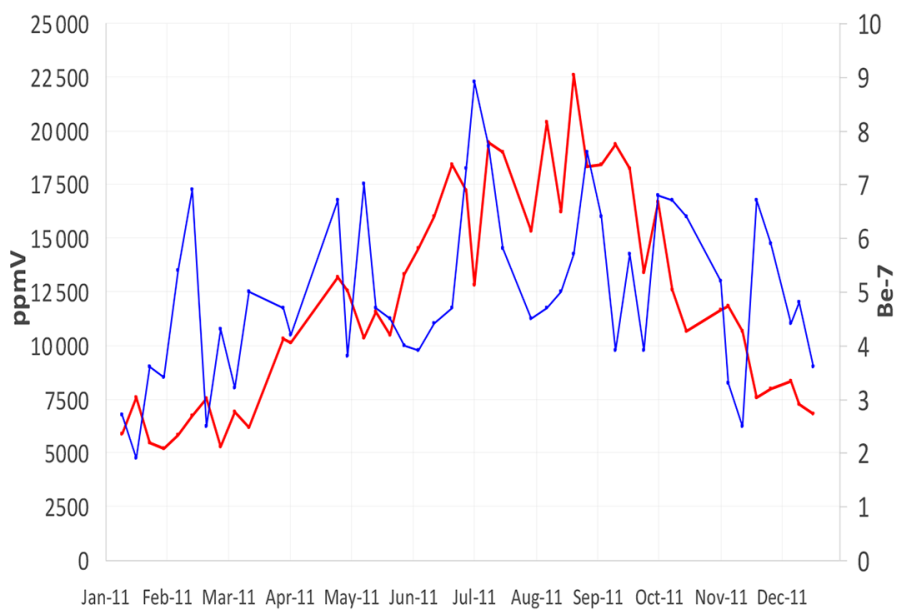

(d)

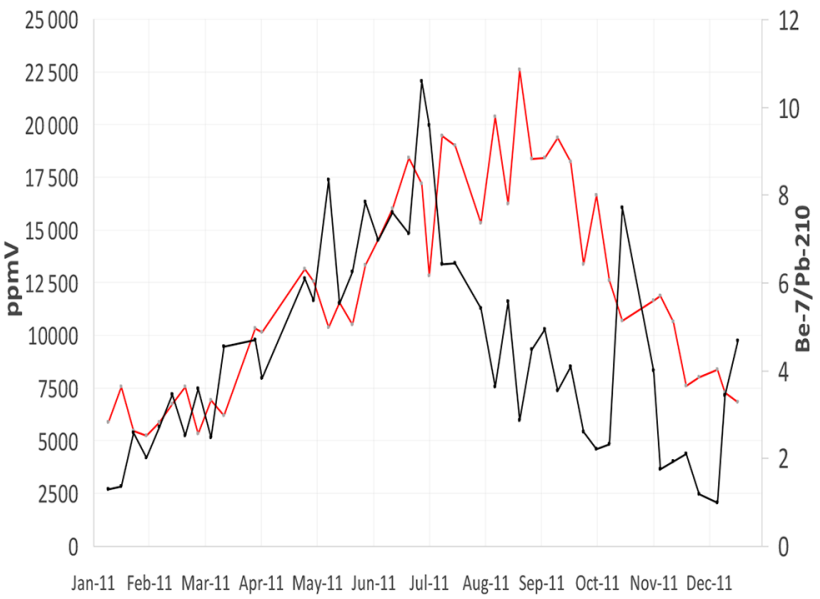

Figure 1. (a) Weekly averages for ozone at 12:00-18:00 (ppb, red) and ${ }^{7} \mathrm{Be}\left(\mu \mathrm{Bq} \mathrm{m}^{-3}\right.$, blue) at the JRC Ispra station for 2011. The authors acknowledge the use of a similar figure in Jensen et al., 2017 (see the "Acknowledgements" section for more details). (b) Weekly averages for ozone at 12:00-18:00 (ppb, red) and ${ }^{7} \mathrm{Be} /{ }^{210} \mathrm{~Pb}$ ratio (black) at the JRC Ispra station for 2011. The authors acknowledge the use of a similar figure in Jensen et al., 2017 (see the "Acknowledgements" section for more details). (c) Weekly averages of the ${ }^{7}$ Be concentrations $\left(\mu \mathrm{Bq} \mathrm{m}{ }^{-3}\right.$, red) and specific humidity at 12:00-18:00 (ppmV, red) at the JRC Ispra station for 2011. (d) Weekly averages of the ${ }^{7} \mathrm{Be} /{ }^{210} \mathrm{~Pb}$ ratio and specific humidity at 12:00-18:00 (ppmV, red) at the JRC Ispra station for 2011.

vs. ${ }^{7} \mathrm{Be} /{ }^{210} \mathrm{~Pb}$ ratios were made for all years during the examined period (2006-2015), and the year 2011 is shown as an example (Fig. 1a, b). As observed, ${ }^{7} \mathrm{Be}$ and $\mathrm{O}_{3}$ peaks coincide in several cases, which might be explained by an impact of deep atmospheric subsidence (air masses moving down from the stratosphere-upper troposphere) on surface ozone. Particularly during springtime, the high ozone levels during such events may be influenced by ozone-rich air being transported down to the boundary layer from the stratosphereupper troposphere.
As seen in Fig. 1a-b, in May 2011 and in a period around the end of June 2011 and beginning of July 2011, there were episodes of downward transport of ozone to the surface from the above tropospheric layers. The relatively higher ${ }^{7} \mathrm{Be} /{ }^{210} \mathrm{~Pb}$ ratios at the end of the spring to the beginning of the summer seasons (mid-April to mid-July) indicate that stratospheric or upper-tropospheric influence should be most important during this period.

In addition, in Fig. $1 \mathrm{c}-\mathrm{d}$ the ${ }^{7} \mathrm{Be}$ activity and the ${ }^{7} \mathrm{Be} /{ }^{210} \mathrm{~Pb}$ ratio are presented together with specific humid- 

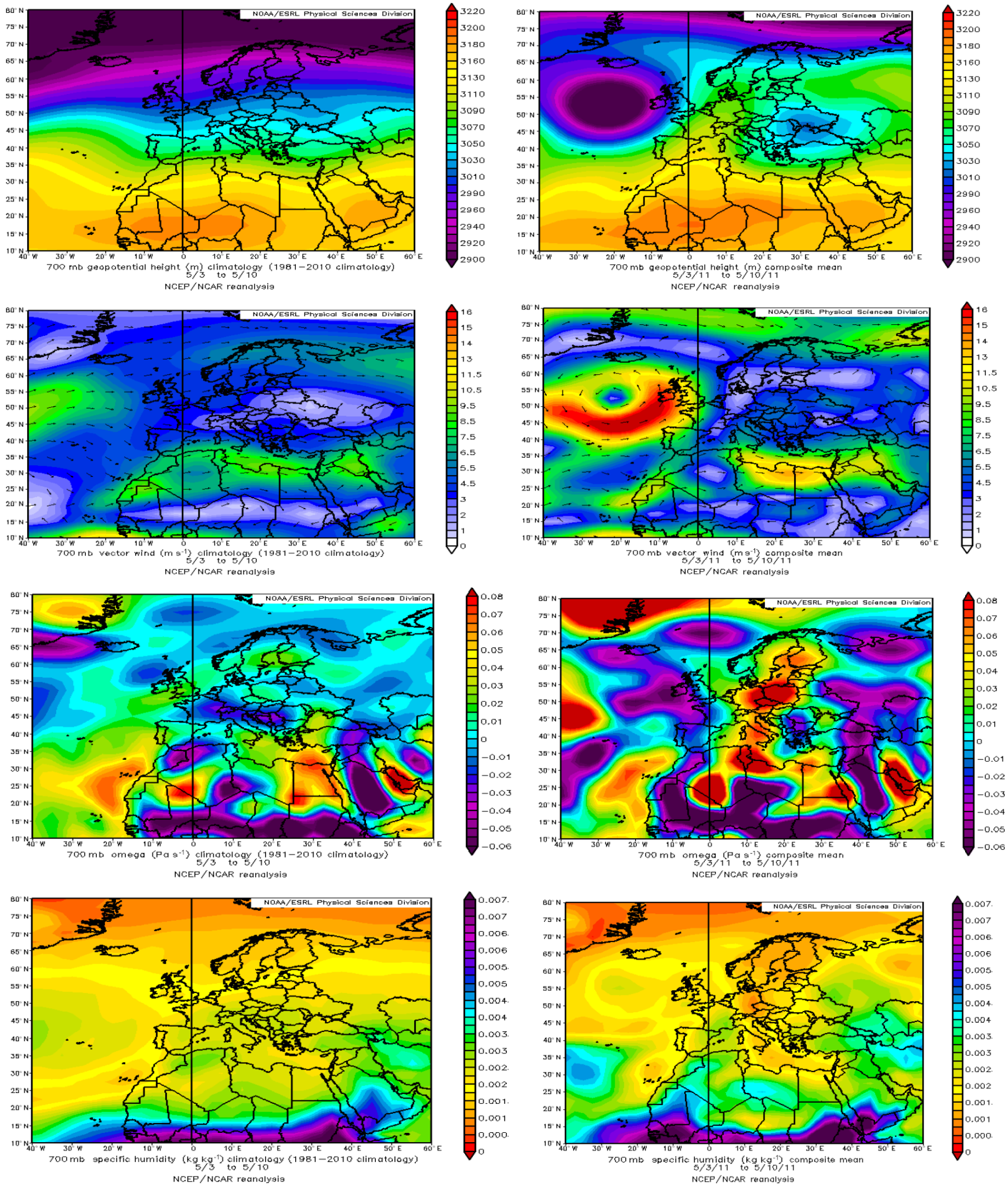

Figure 2. Composite NOAA/ESRL weather maps of geopotential height, vector wind speed, omega vertical velocity and specific humidity for 3-10 May climatology (left column) and for the episode of 3-10 May 2011 at JRC Ispra, Italy (right column). 
ity. As observed, very often the local ${ }^{7} \mathrm{Be} /{ }^{210} \mathrm{~Pb}$ maxima coincide with local minima of specific humidity, which supports the assumption that this isotope ratio is an indicator of the relative importance of entrainment of subsiding dry air originating from the upper atmospheric layer into the boundary layer and the ground surface. The ${ }^{7} \mathrm{Be}$ activity does not show a similar correlation with specific humidity. If we look at the yearly variation in the isotope ratio, it has a maximum in the early summer while specific humidity has a maximum later in the summer, which may be explained by the fact that warm air can contain more water vapor.

The ${ }^{7} \mathrm{Be} /{ }^{210} \mathrm{~Pb}$ peaks in some cases coincide with ozone peaks, but local ${ }^{7} \mathrm{Be}$ activity peaks are found to more frequently coincide with local ozone maxima. Thus the radioisotope data are consistent with the hypothesis that maximum ozone values are frequently reached in situations where there is a combined impact of entrainment of ozone-rich air brought down by subsidence (high ${ }^{7} \mathrm{Be}$ activities) and stagnant atmospheric conditions (high ${ }^{210} \mathrm{~Pb}$ activities), favoring ozone formation in the boundary layer. In such conditions, ${ }^{7} \mathrm{Be}$ activities will be high, but not the ${ }^{7} \mathrm{Be} /{ }^{210} \mathrm{~Pb}$ ratio. This is illustrated in Fig. 1 for the year 2011, but a similar picture is seen during other years, where observations are available (see Fig. S1-S4 in the Supplement).

As reported in the literature, stratospheric ozone intrusions in the Mediterranean occur most frequently from March to July (Beekmann et al., 1994; Monks et al., 2000). An ozone increase is generally observed during spring months, associated with the increase in solar radiation and photochemistry (Monks et al., 2000) but also with tropospheric downward transport (Kalabokas et al., 2017), and thus some caution would be needed in the data analysis as the increase in $\mathrm{O}_{3}$, ${ }^{7} \mathrm{Be}$ and ${ }^{7} \mathrm{Be} /{ }^{210} \mathrm{~Pb}$ at the same time is not necessarily related to the impact of stratospheric intrusions. However, the occurrence of ${ }^{7} \mathrm{Be} /{ }^{210} \mathrm{~Pb}$ peaks above the baseline level can be interpreted as evidence of deep atmospheric subsidence followed by entrainment into the boundary layer. The episodes in May and June 2011 with high ozone and ${ }^{7} \mathrm{Be} /{ }^{210} \mathrm{~Pb}$ values (Fig. 1) appears to be due to such deep tropospheric subsidence as indicated by synoptic meteorological maps, back trajectories and IASI satellite data. Such specific episodes will be examined in detail later in the following section.

Table 2 shows the average monthly values for spring, summer and autumn (March to October) of ${ }^{7} \mathrm{Be},{ }^{7} \mathrm{Be} /{ }^{210} \mathrm{~Pb}$ and $\mathrm{O}_{3}$ (12-18 afternoon mean) for all of the years 2006-2015 when measurements were available. The ${ }^{7} \mathrm{Be}$ concentrations show maximum monthly values in June-July, the same as ozone, while the ${ }^{7} \mathrm{Be} /{ }^{210} \mathrm{~Pb}$ ratio has its peak values in the April-June period, which would indicate enhanced deep tropospheric subsidence during this period of the year.
Table 2. Monthly averages of ${ }^{7} \mathrm{Be},{ }^{210} \mathrm{~Pb}$, ozone (12:00-18:00) concentrations and ${ }^{7} \mathrm{Be} /{ }^{210} \mathrm{~Pb}$ ratio during the March-October period (2006-2015).

\begin{tabular}{lrrrr}
\hline Month & $\begin{array}{r}{ }^{7} \mathrm{Be} \\
\left(\mu \mathrm{Bq} \mathrm{m}^{-3}\right)\end{array}$ & $\begin{array}{r}{ }^{210} \mathrm{~Pb} \\
\left(\mu \mathrm{Bq} \mathrm{m}^{-3}\right)\end{array}$ & $\begin{array}{r}{ }^{7} \mathrm{Be} /{ }^{210} \mathrm{~Pb} \\
\text { ratio }\end{array}$ & $\begin{array}{r}\mathrm{O}_{3} \\
(\mathrm{ppb})\end{array}$ \\
\hline 3 & 4031.2 & 875.3 & 6.1 & 25.0 \\
4 & 4737.1 & 835.4 & 7.1 & 34.9 \\
5 & 4741.0 & 726.7 & 7.3 & 40.2 \\
6 & 4863.8 & 794.4 & 7.0 & 52.6 \\
7 & 5824.5 & 1049.7 & 6.6 & 52.5 \\
8 & 5272.3 & 1114.8 & 5.7 & 36.5 \\
9 & 4490.8 & 1090.8 & 4.7 & 25.4 \\
10 & 4249.3 & 1609.7 & 3.6 & 16.3 \\
\hline
\end{tabular}

\subsection{Investigation of the main synoptic characteristics during the May-July ozone episodes}

As the May-July period seems to be the most important one regarding the influence of subsidence on ozone concentrations, as a next step selected weekly high ${ }^{7} \mathrm{Be}$ and ozone episodes during the May-July period will be examined. More than 10 weekly ${ }^{7} \mathrm{Be}$ and ozone episodes were identified in the whole time series and the three most characteristic of them, for what concerns signs of tropospheric subsidence as observed in the meteorological and air pollution measurements (high ${ }^{7} \mathrm{Be}$ and $\mathrm{O}_{3}$ concentrations combined with positive omega and dry air masses), will be presented in the following paragraphs. The selected episodes were 3-10 May 2011, 23-29 May 2012 and 28 June-4 July 2011. The episodes discussed here are not Foehn events.

\subsubsection{May 2011 ozone episode}

In Fig. 2 the composite NOAA/ESRL weather maps of geopotential height, wind speed, omega vertical velocity and specific humidity for the episode of 3-10 May 2011 (as well as the corresponding 3-10 May climatology charts) at JRC Ispra are shown. A strong low-pressure system is observed over the Atlantic and a weaker one over eastern Europe and the Black Sea while anticyclonic conditions prevail over western and central Europe in a vast region extending from Scandinavia to the Mediterranean. In this region strong subsidence is observed as deduced from the charts of omega vertical velocity and specific humidity, indicating large-scale downward movement of dry air masses. Similar subsidence conditions have already been observed during regional spring ozone episodes over the western Mediterranean, especially related to the interface of an anticyclone and a low-pressure system located further east (Kalabokas et al., 2017). 

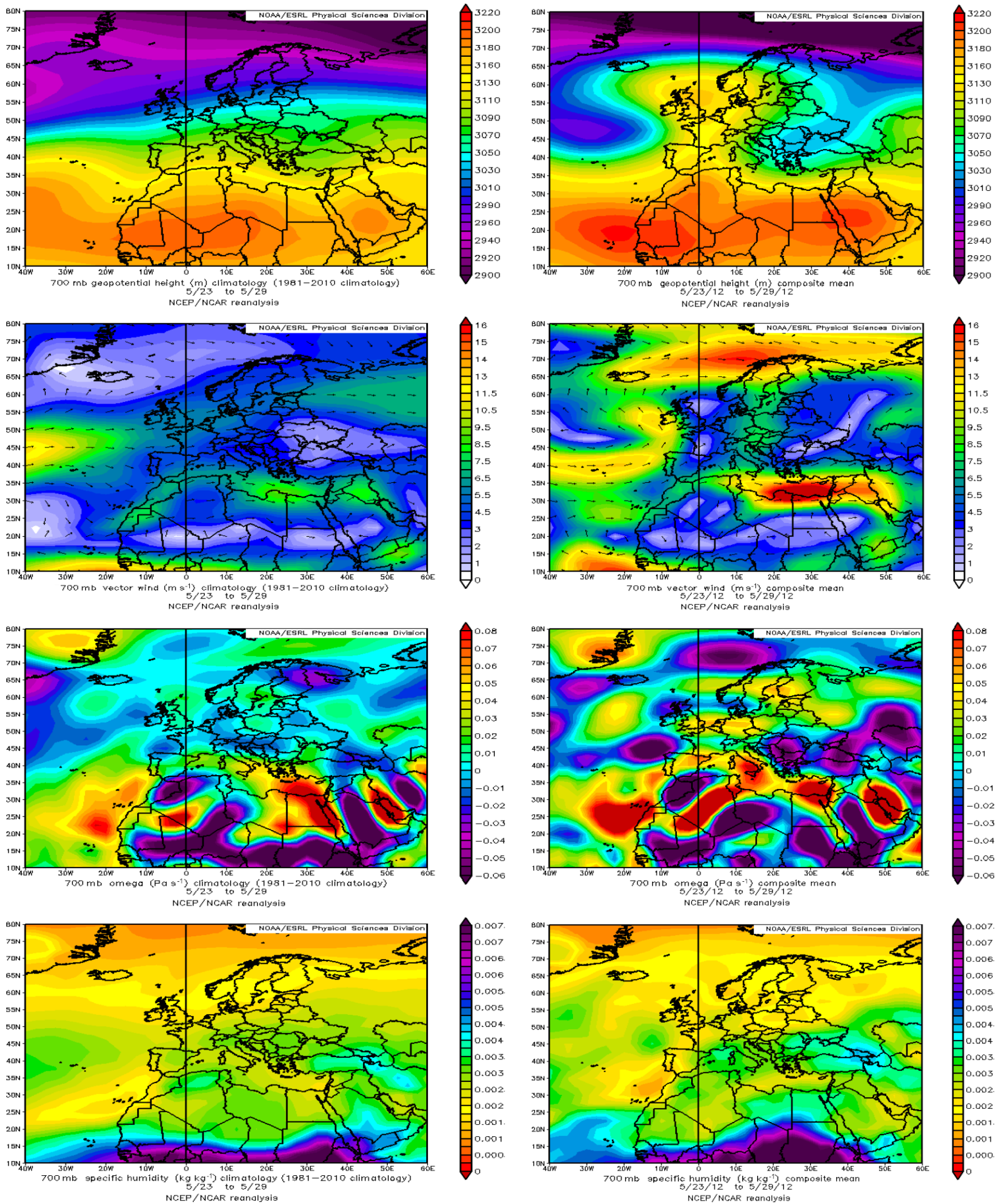

Figure 3. Composite NOAA/ESRL weather maps of geopotential height, vector wind speed, omega vertical velocity and specific humidity for 23-29 May climatology (left column) and for the episode of 23-29 May 2012 at JRC Ispra, Italy (right column). 

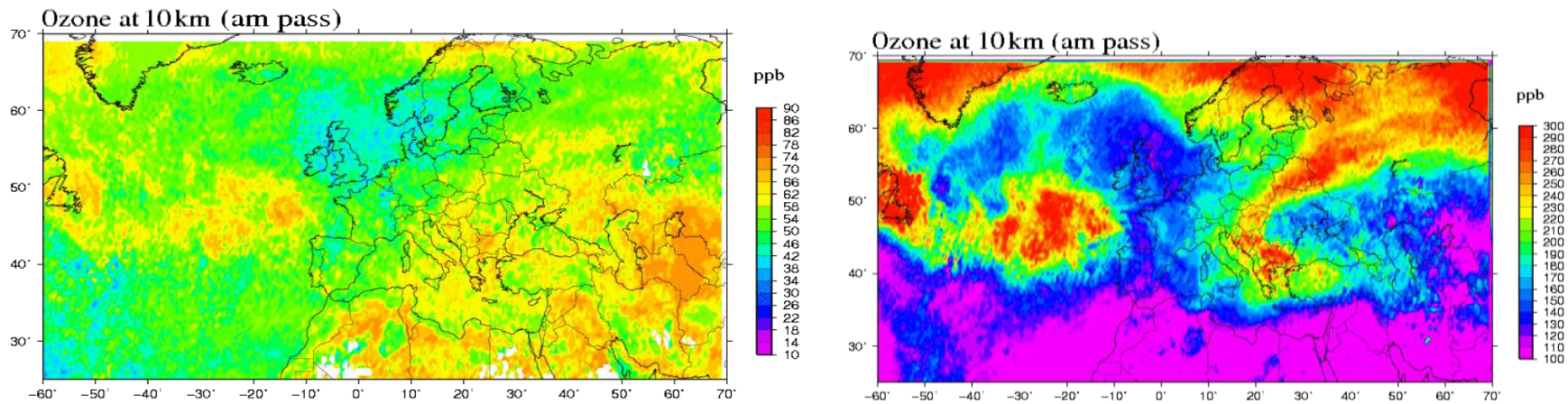

IASI/MetOp $20120523 \_20120524$

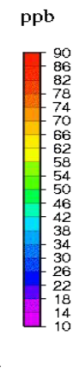

IASI/MetOp 20120523_20120524
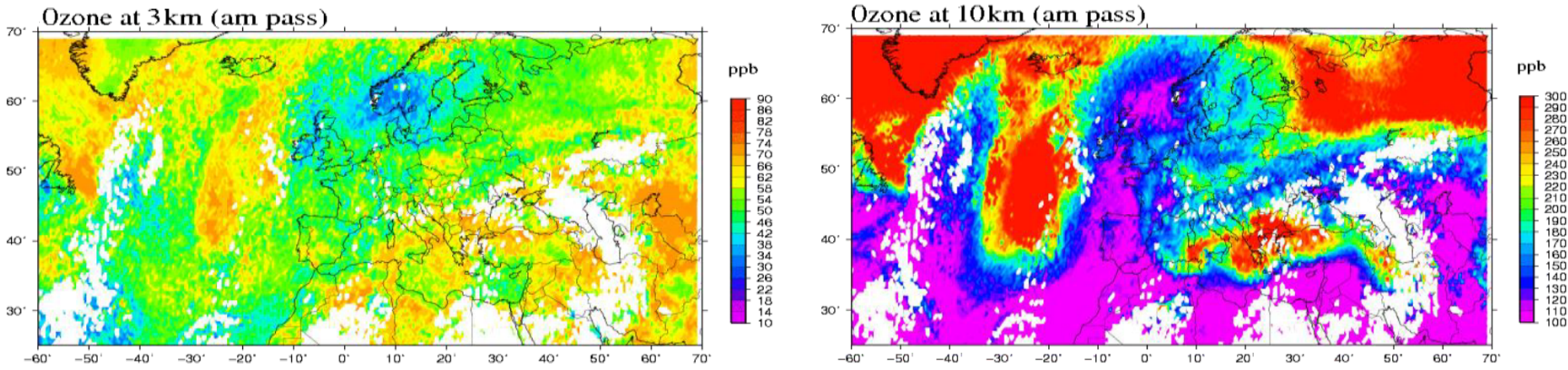

IASI/MetOp $20120525 \_20120527$

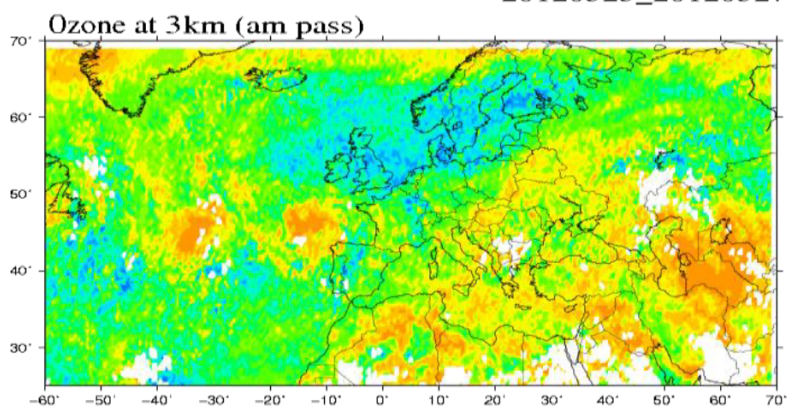

IASI/MetOp 20120528_20120529

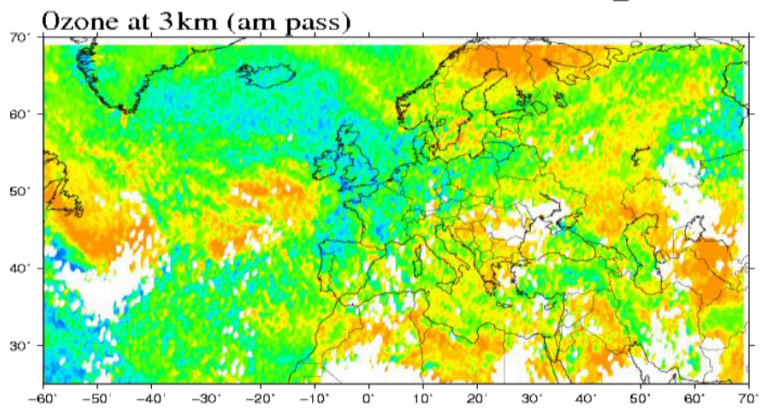

IASI/MetOp 20120525_20120527

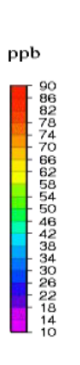

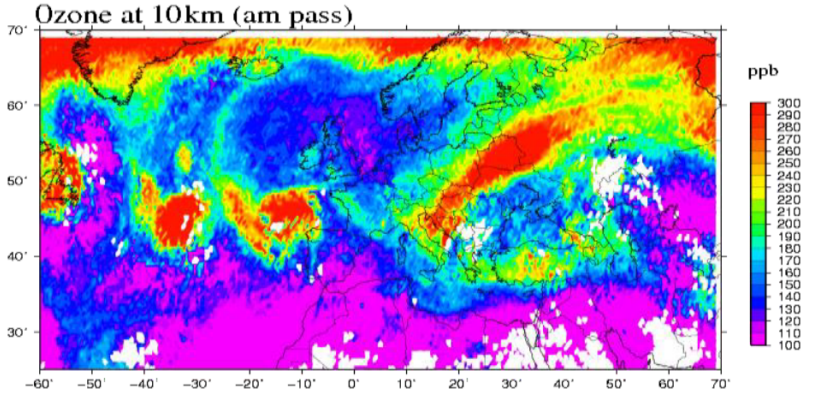

IASI/MetOp 20120528_20120529

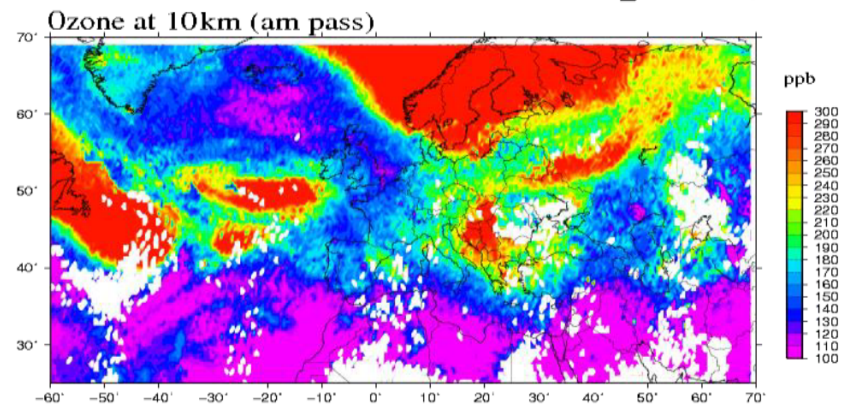

Figure 4. IASI satellite images for ozone concentration at $3 \mathrm{~km}$ (left column) and $10 \mathrm{~km}$ (right column) for the episode of $23-29 \mathrm{May} 2012$. Starting from the top: 23-29, 23-24, 25-27 and 28-29 May. 

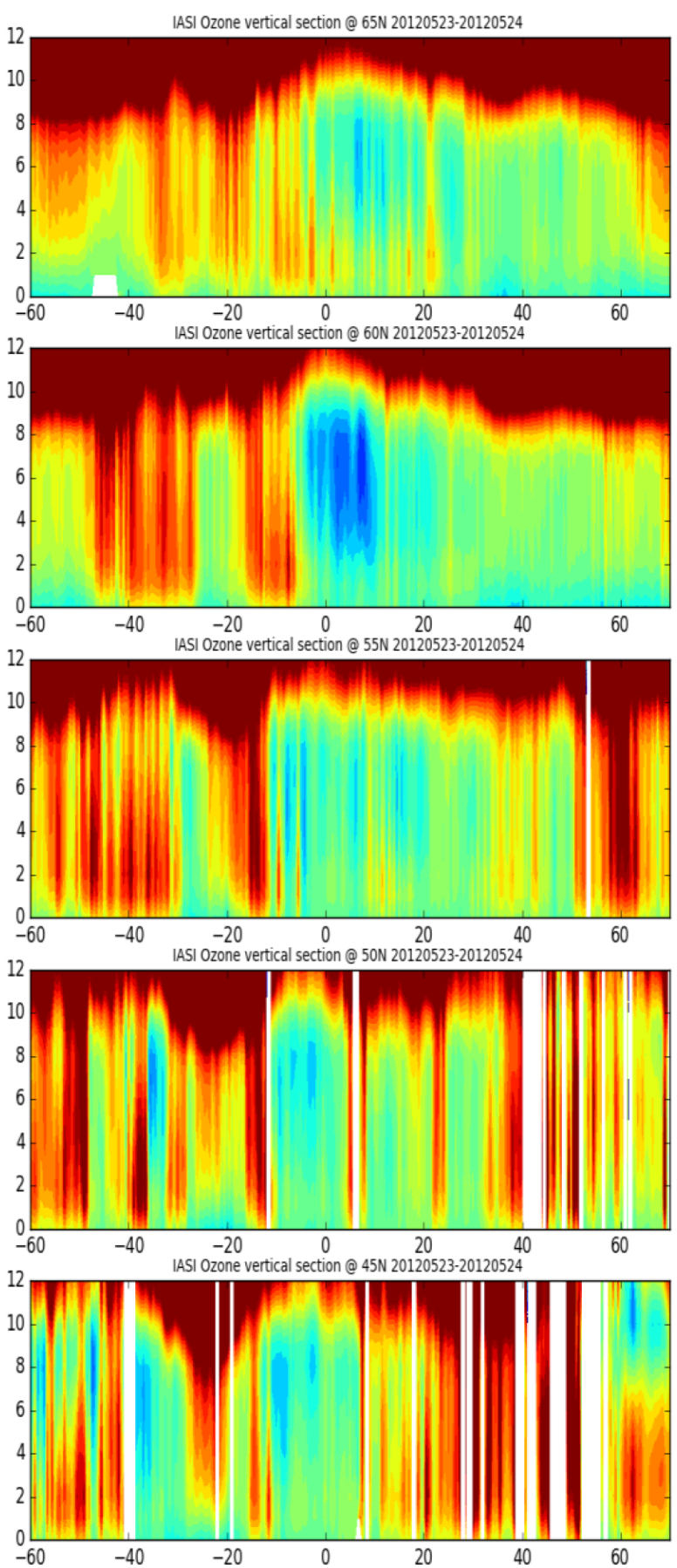
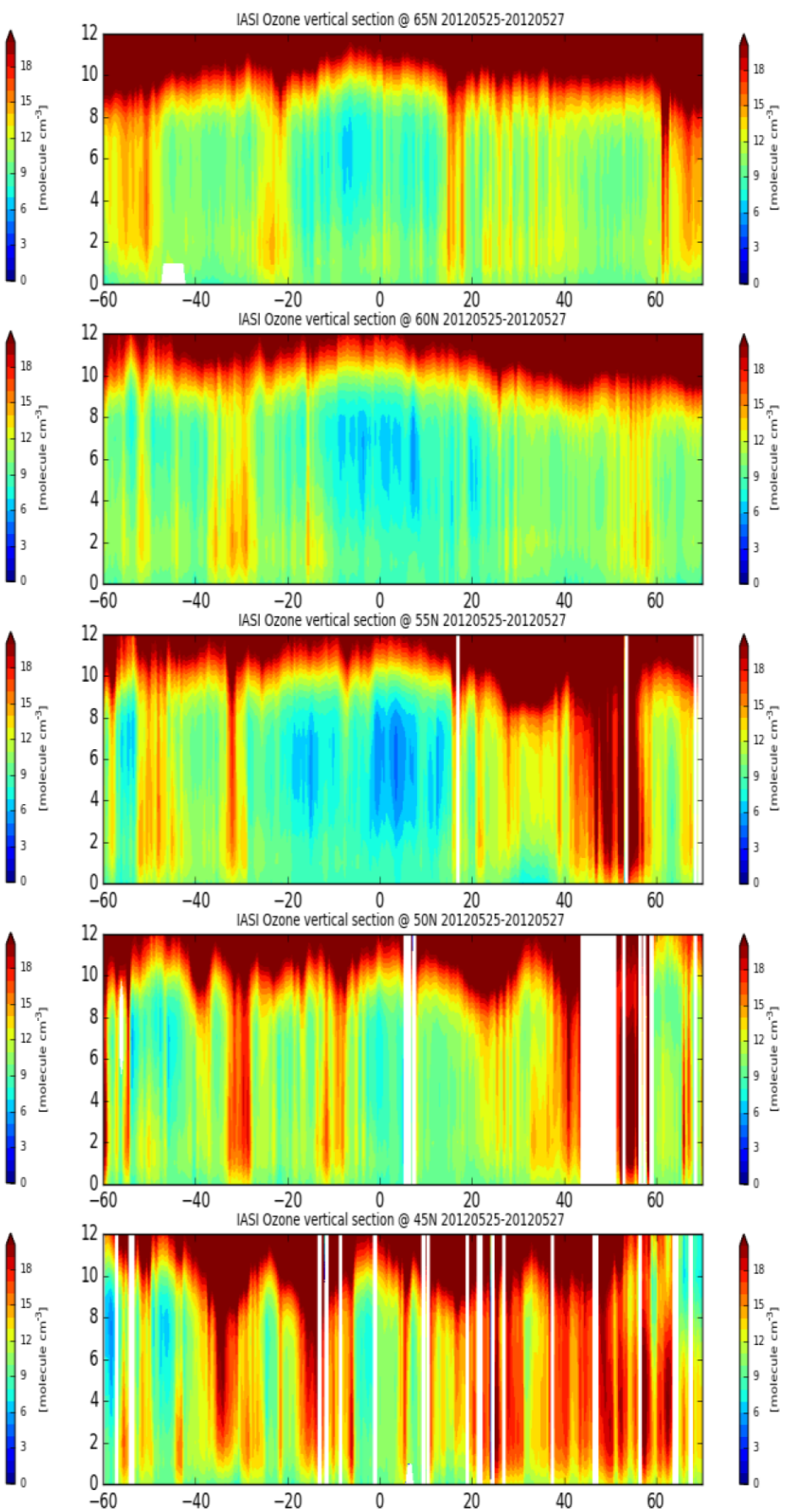

Figure 5. IASI vertical sections at various latitudes from $65^{\circ} \mathrm{N}$ (upper panel) to $45^{\circ} \mathrm{N}$ (lower panel) on $23-24 \mathrm{May} 2012$ (left column) and on 25-27 May 2012 (right column).

\subsubsection{May 2012 ozone episode}

The above feature is also clearly seen in the following selected episode of 23-29 May 2012 (Fig. 3), with a much stronger anticyclone established over the North Sea (weekly averages measured at Ispra: ${ }^{7} \mathrm{Be}: 7117 \mu \mathrm{Bq} \mathrm{m}{ }^{-3} ;{ }^{7} \mathrm{Be} /{ }^{210} \mathrm{~Pb}$ ratio: 9.6; ozone: $54.9 \mathrm{ppb})$. The corresponding IASI and
IASI + GOME-2 satellite images as well as IASI vertical sections at various latitudes from 60 to $45^{\circ} \mathrm{N}$ for ozone concentration at $3 \mathrm{~km}$ and $10 \mathrm{~km}$ are shown in Figs. 4-6. The IASI + GOME-2 maps show enhanced ozone concentrations at $3 \mathrm{~km}$ over Germany, France and Italy, which seem disconnected from the values at $10 \mathrm{~km}$. In a general way, IASIGOME-2 ozone concentrations at $3 \mathrm{~km}$ seem more indepen- 
IASI+GOME2/MetOp 20120523-20120529
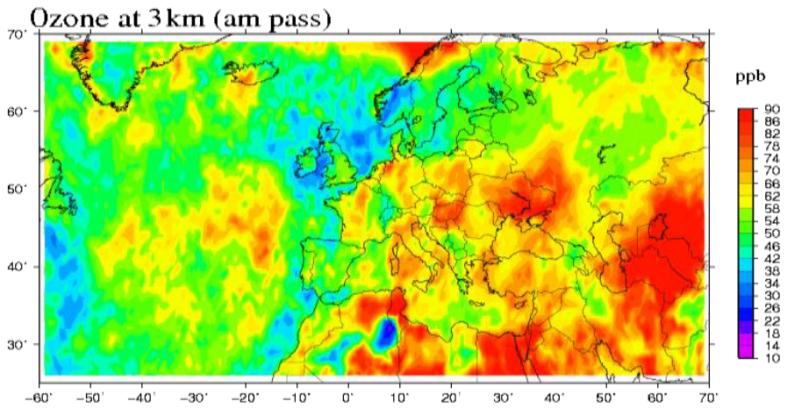

IASI+GOME2/MetOp 20120523-20120524
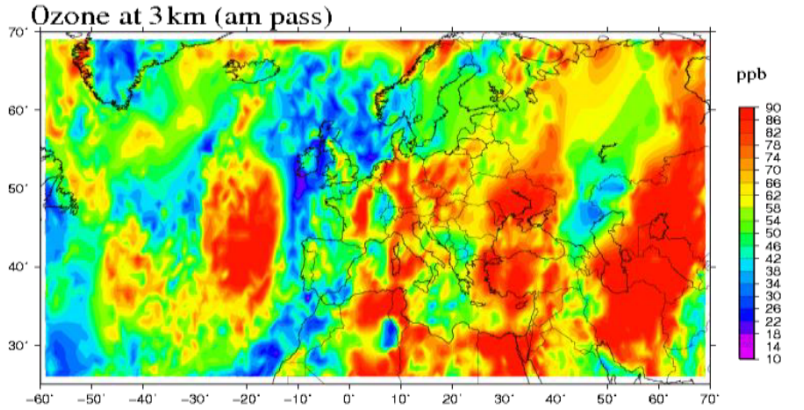

IASI+GOME2/MetOp 20120525-20120527
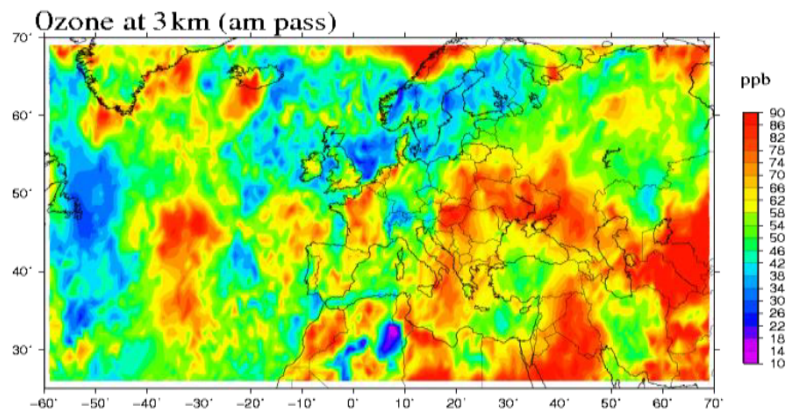

IASI+GOME2/MetOp 20120528-20120529
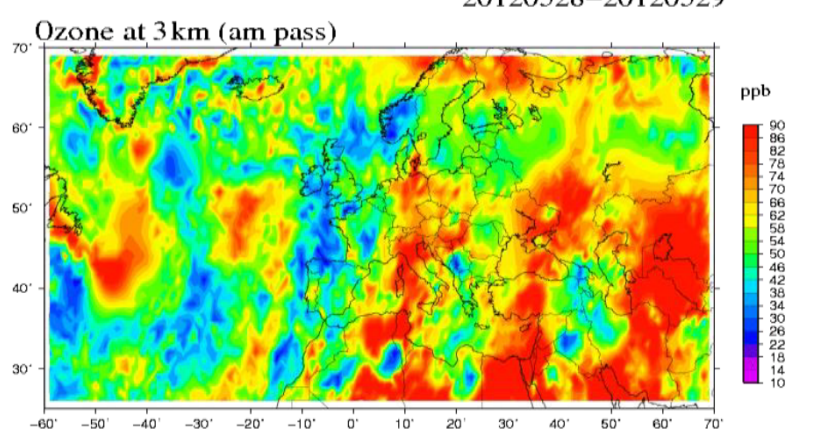

IASI+GOME2/MetOp 20120523-20120529

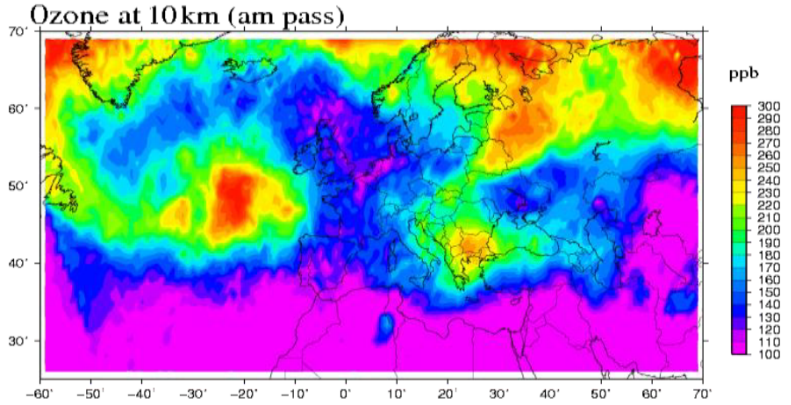

IASI+GOME2/MetOp 20120523-20120524

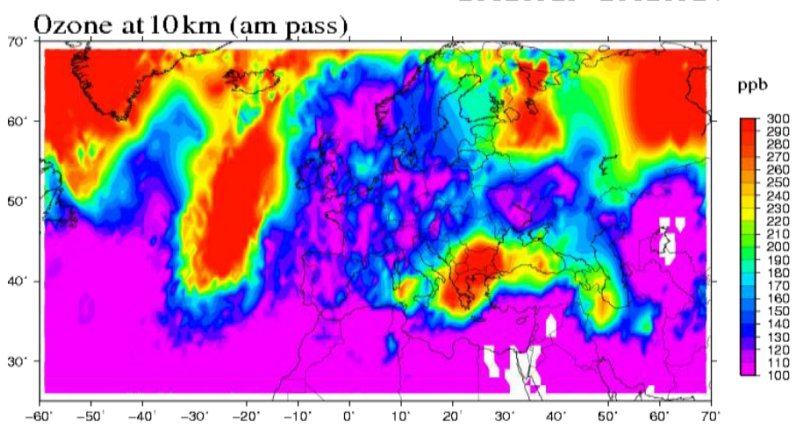

ASI+GOME2/MetOp 20120525-20120527

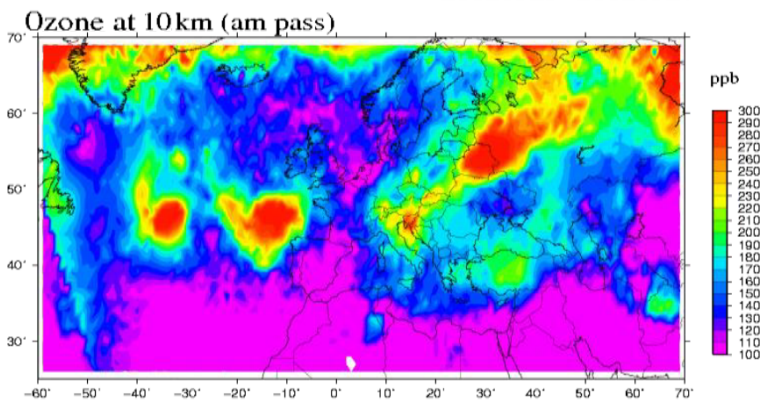

IASI+GOME2/MetOp $20120528-20120529$

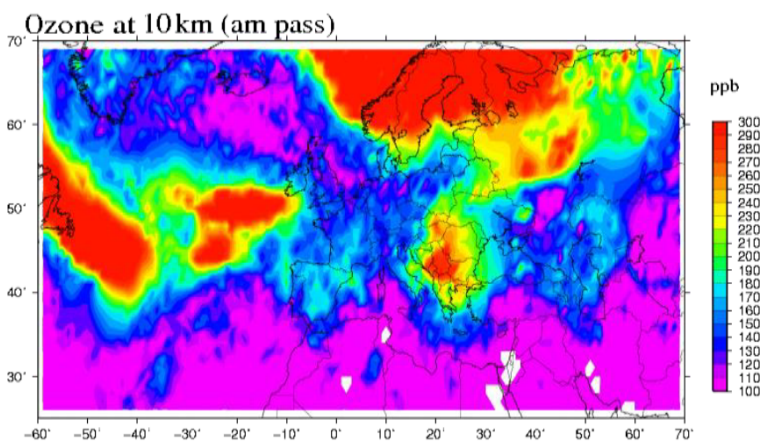

Figure 6. IASI + GOME-2 satellite images for ozone concentration at $3 \mathrm{~km}$ (left column) and $10 \mathrm{~km}$ (right column) for the episode of 23-29 May 2012. Starting from the top: 23-29, 23-24, 25-27 and 28-29 May. 
dent of those at $10 \mathrm{~km}$ than are those derived from IASI at the same altitudes, which is expected because the number of degrees of freedom is larger. It appears that the geographical distribution of tropospheric ozone as well as the movement of the high-ozone reservoirs at both altitude levels generally follow the synoptic weather patterns (Figs. 3, 4). An extended high-ozone area appears to the east of the anticyclone at both tropospheric levels apparently originating from the north and is an extension of the northern polar high-ozone reservoir. It has to be added that back trajectories show air masses arriving at the Ispra site from the N-NE direction and from higher altitudes, especially on 25-27 May (not shown). This behavior is usually encountered in the analysis of many spring ozone episodes over the area as the $6 \mathrm{~d}$ back trajectories usually originate from the region of high tropospheric ozone subsidence over central and eastern Europe, thus inducing high ozone background levels of tropospheric origin at the boundary layer and at the surface to which the photochemical ozone buildup might eventually be added.

\subsubsection{June-July 2011 ozone episode}

The next episode of 28 June-4 July 2011 seems to be quite representative of early summer ozone episodes over the area and will be examined in more detail by taking into account many relevant atmospheric measurements recorded at the JRC Ispra station. During this episodic event, very high ${ }^{7} \mathrm{Be}$ concentrations as well as ${ }^{7} \mathrm{Be} /{ }^{210} \mathrm{~Pb}$ ratio values have been recorded, which were actually the highest weekly averages for 2011 (Fig. 1a, b). Regarding the weather conditions, it has been mostly sunny throughout the week with some rain on the second day and light northwesterly winds.

The synoptic conditions (Figs. 7-8, S5) show the existence of an extended deep low-pressure system over the Atlantic in the free troposphere (at 500-700 hPa) and also another one over central Europe in the boundary layer (at 700-1000 hPa), while high atmospheric pressure prevails over most of the European continent, including Scandinavia. Following the examination of the meteorological charts, it has been observed that massive subsidence occurs over a wide area over the Atlantic and western Europe towards the Mediterranean, including the Alpine region, peaking on 1-3 July. Indeed, specific humidity charts at various pressure levels (Fig. S5) show an extended area of dry air masses over the Atlantic (northern Spain and western France) at lower latitudes, moving towards the European continent and the Mediterranean following the synoptic flow (Fig. 7). The omega vertical velocity charts show that the descending motion is stronger at higher altitudes but at the same time there is an accumulation of dry air masses over the Atlantic (indicating subsidence), which are displaced according to the above-described synoptic pattern. In addition, the tropospheric ozone distribution as measured by the IASI and IASI + GOME-2 satellites at 3 and $10 \mathrm{~km}$ follows the synoptic patterns (Figs. 9-11). As observed on 30 June and 1 July, there is a large zone of en- hanced ozone at $10 \mathrm{~km}$, but also at $3 \mathrm{~km}$, descending from the North Sea to the Alps, and which corresponds to a through east of the ridge. On 2 and 3 July, the trough developed to a cutoff low located over SE Poland and so did high ozone values at $10 \mathrm{~km}$.

The above-described characteristics related to subsidence are much more pronounced if only 1-2 July is considered, especially the large-scale descending tendency of tropospheric air masses at all pressure levels over central and northern Europe, which is subsequently associated with extended tropospheric dryness over these areas (Figs. S6-S8).

In addition, according to the back-trajectory plots the subsiding air masses arrive at the JRC Ispra site from the Atlantic coast and France (Fig. 16). Almost all back trajectories arrive from the north, where the subsidence area is located (Figs. 910, S5) and where a large area of tropospheric ozone appears over western Europe, apparently originating from the highozone reservoir located over polar regions as shown in the corresponding IASI and IASI + GOME-2 satellite images as well as IASI vertical sections (Figs. 9-11).

The hourly air pollution measurements at the JRC station during the 28 June-4 July 2011 period first show a period (28 and 29 June) with high ozone (daily maximum more than $80 \mathrm{ppb}$ ) and $\mathrm{PM}_{10}$ (daily maximum more than $80 \mu \mathrm{g} \mathrm{m}^{-3}$ ), related to high temperatures $\left(T_{\max } 30^{\circ} \mathrm{C}\right.$ and low wind speed $\left(<1 \mathrm{~m} \mathrm{~s}^{-1}\right)$. Aerosol is of mainly anthropogenic origin as indicated by different nephelometer responses to red, green and blue light. High ozone values during this period are probably due mainly to photochemical buildup from anthropogenic emissions in the Po valley. During the following period with a maximum of subsidence (1-2 July), ozone concentrations vary around 55-60 ppb with the diurnal concentration range significantly decreased in comparison to the previous days while at the same time the $\mathrm{NO}_{x}$ concentrations (Fig. 13a) as well as the humidity, ${ }^{222} \mathrm{Rn}$, nephelometer and $\mathrm{PM}_{10}$ concentrations (Fig. 13b-d) show minimum values. Please note that the weekly resolution of ${ }^{7} \mathrm{Be}$ measurements does not allow for ascertaining an expected maximum during these $2 \mathrm{~d}$. During the days following the strongest subsidence period (3-4 July) the nocturnal ozone values are significantly reduced as the tropospheric entrainment has diminished while the ozone destruction by NO chemical titration and dry deposition on the ground reduces the concentrations substantially within the generally shallow nocturnal layer. On the other hand, the midday ozone concentrations are slightly increased, probably due to in situ photochemical ozone production, which is added to the increased tropospheric ozone background, due to the regional tropospheric subsidence episode occurring during the previous days. Thus, this period shows an interesting suite of days with strong photochemical ozone production and advection of tropospheric ozone to the ground.

In summarizing the above, it has to be mentioned at first that maximum ozone values in the area of the study are expected to be connected primarily with boundary layer ozone photochemistry. The presented analysis shows that regional 

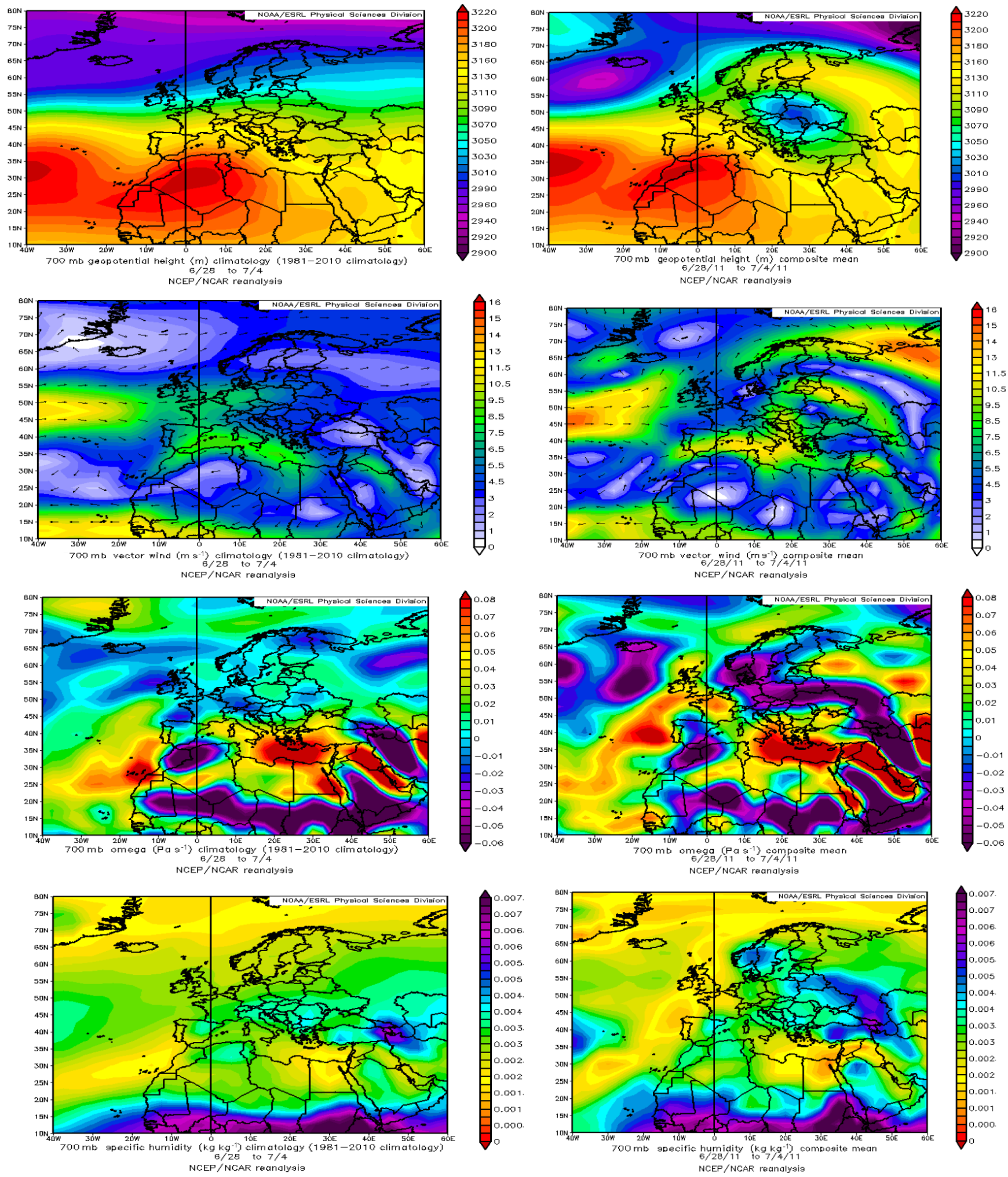

Figure 7. Composite NOAA/ESRL weather maps of geopotential height, vector wind speed, omega vertical velocity and specific humidity for 28 June-4 July 2011 climatology (left column) and for the episode of 28 June-4 July 2011 at JRC Ispra, Italy (right column). 

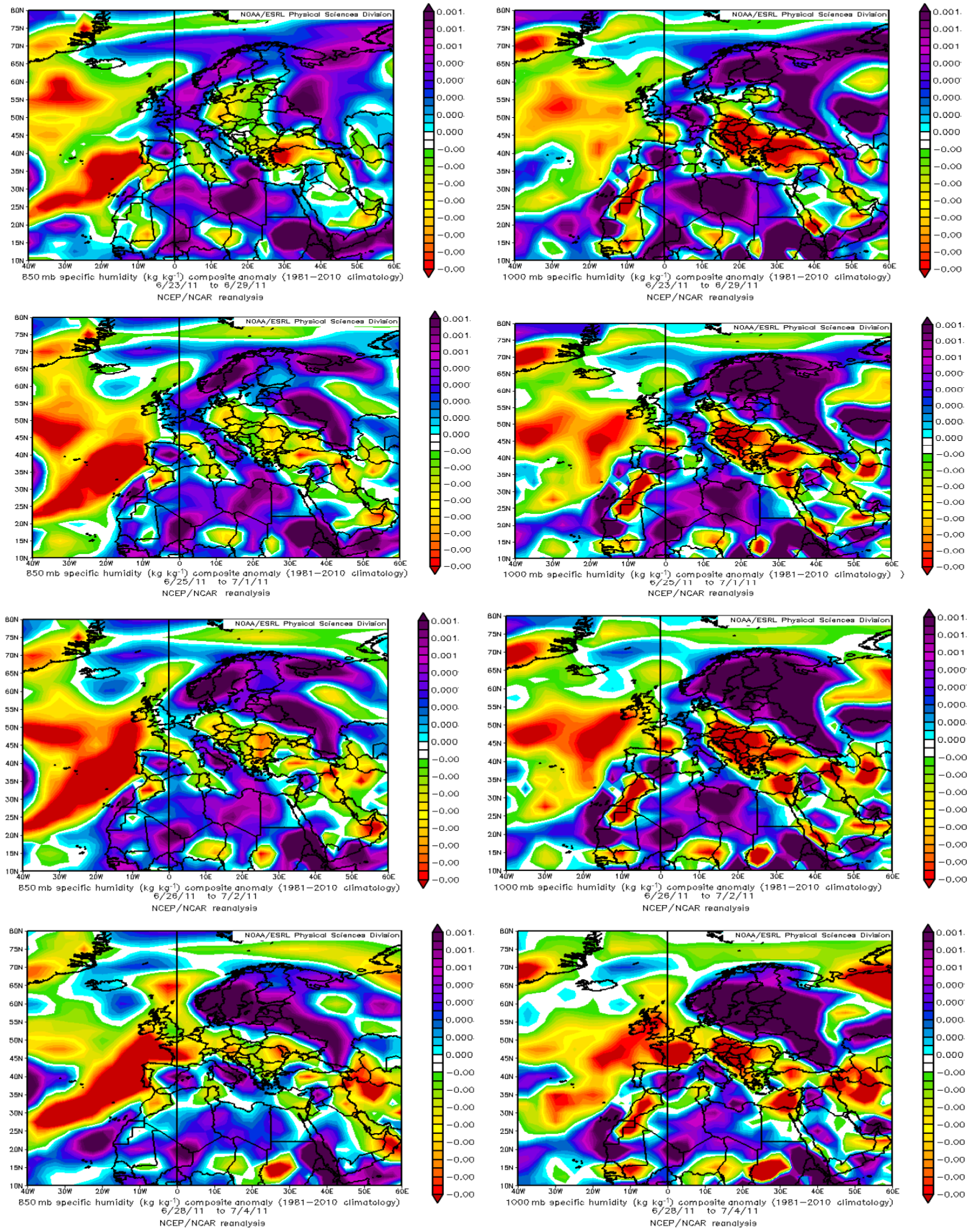

Figure 8. Composite charts for specific humidity anomaly at $850 \mathrm{hPa}$ (left column) and at $1000 \mathrm{hPa}$ (right column), 5,3 and $2 \mathrm{~d}$ before and during the episode of 28 June-4 July 2011 (lower panels). 

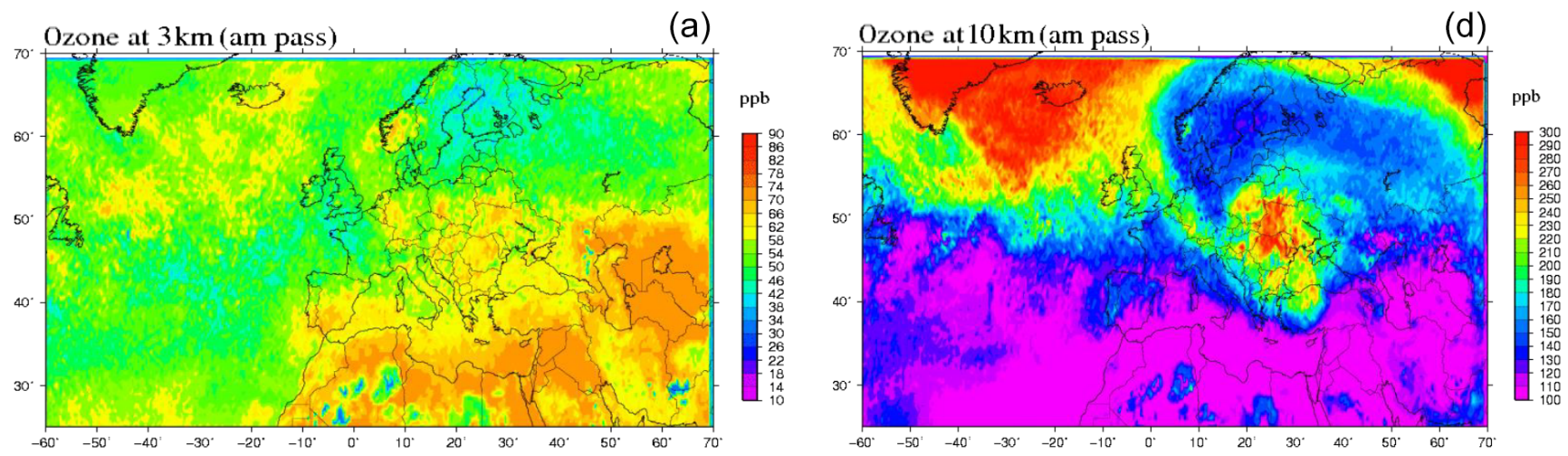

IASI/MetOp
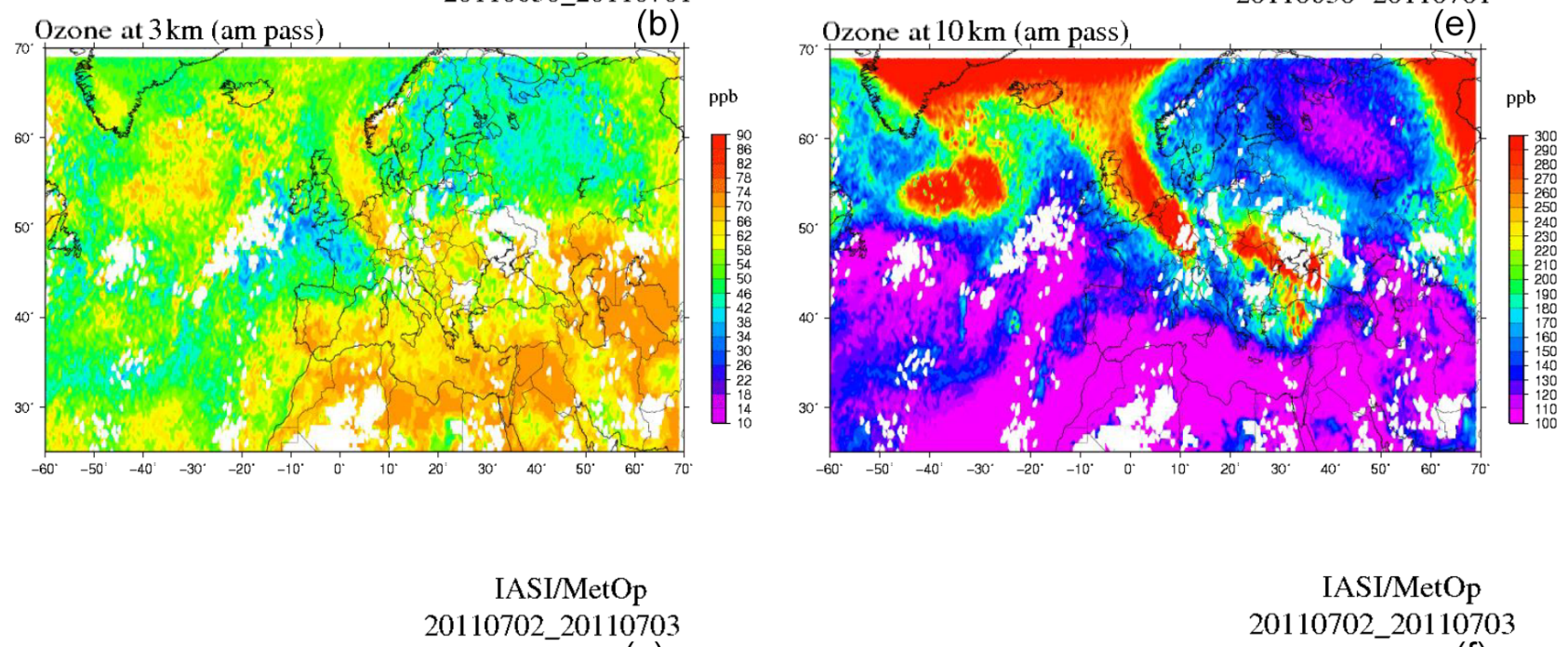

(c)
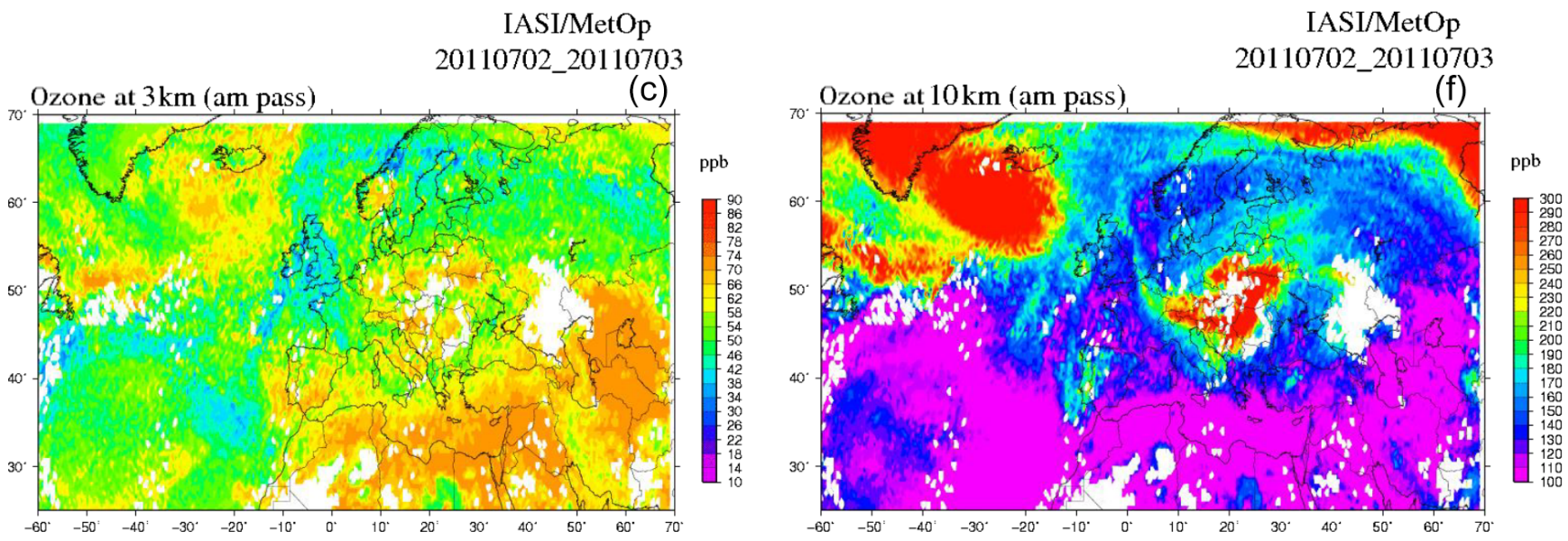

Figure 9. IASI satellite images of ozone concentration at $3 \mathrm{~km}(\mathbf{a}, \mathbf{b}, \mathbf{c})$ and $10 \mathrm{~km}(\mathbf{d}, \mathbf{e}, \mathbf{f})$ for the episode of $28 \mathrm{June}-4 \mathrm{July} 2011$. Starting from the top: 28 June-4 July, 30 June-1 July and 2 July-3 July.

tropospheric subsidence occurring frequently in the area during May-July might enable easier exceedances of ozone air quality standards, as photochemical ozone buildup is initiated in a clean boundary layer air mass containing already high ozone levels (i.e., $50 \mathrm{ppb}$ ), which is common after a regional tropospheric subsidence episode in the area. This phenomenon may explain the spring ozone maximum observed over many stations over the western and central parts of the 

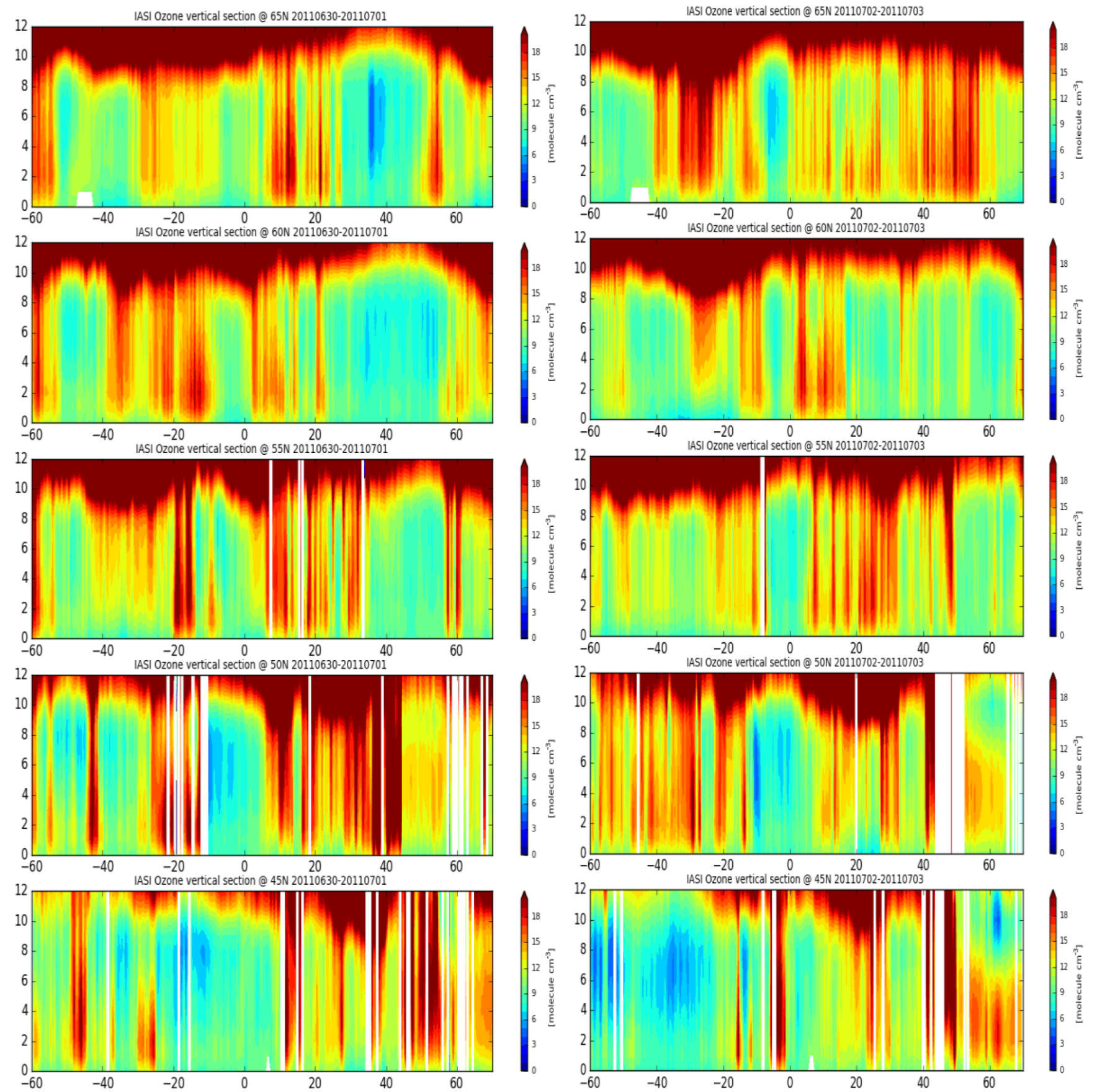

Figure 10. IASI vertical sections at various latitudes from $65^{\circ} \mathrm{N}$ (upper panel) to $45^{\circ} \mathrm{N}$ (lower panel) on $30 \mathrm{June}-1 \mathrm{July} 2011$ (left column) and on 2-3 July 2011 (right column).

European continent including the western Mediterranean. In relation to the above, it has been mentioned in the introduction that a similar phenomenon is observed in the eastern Mediterranean, reaching a maximum later in summer though (July-August).

\section{Conclusions}

The present study focuses on the influence of tropospheric subsidence on surface ozone concentrations, especially during spring and summer months over the western Mediterranean area. It is a much more detailed extension of a previous study (Kalabokas et al., 2017) where some tropospheric mechanisms related with regional ozone episodes in partic- 
IASI+GOME2/MetOp 20110628-20110704
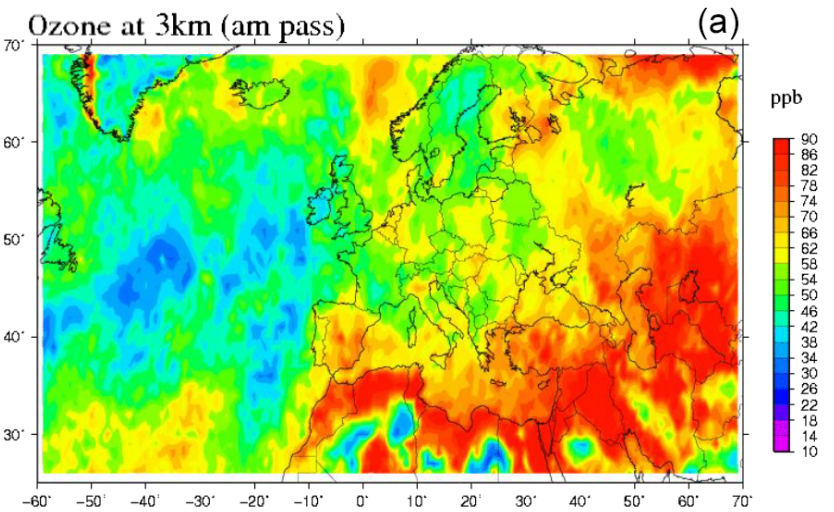

IASI+GOME2/MetOp

20110628-20110704

(d)

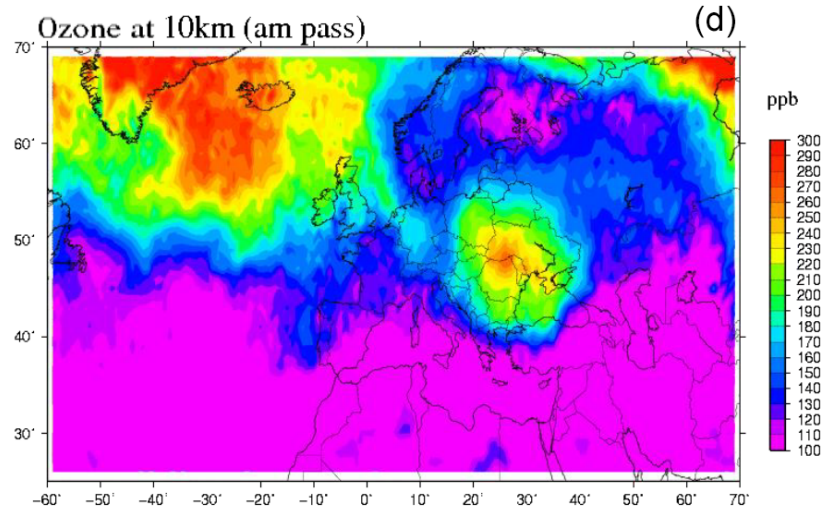

IASI+GOME2/MetOp 20110630-20110701

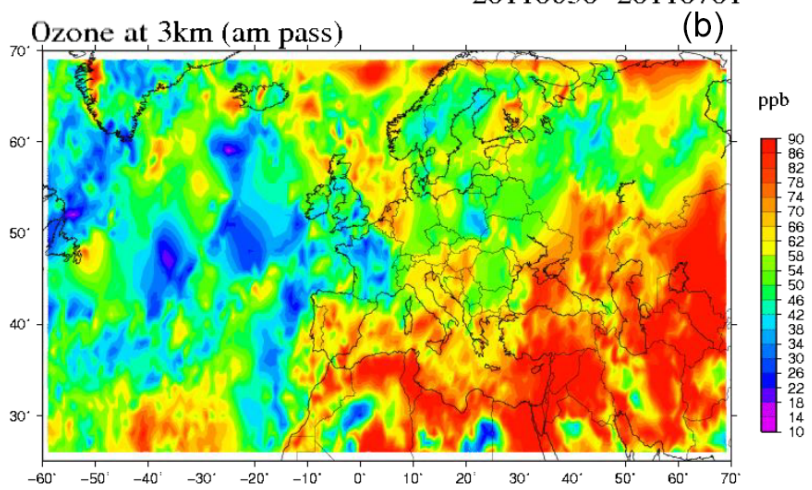

IASI+GOME2/MetOp 20110630-20110701

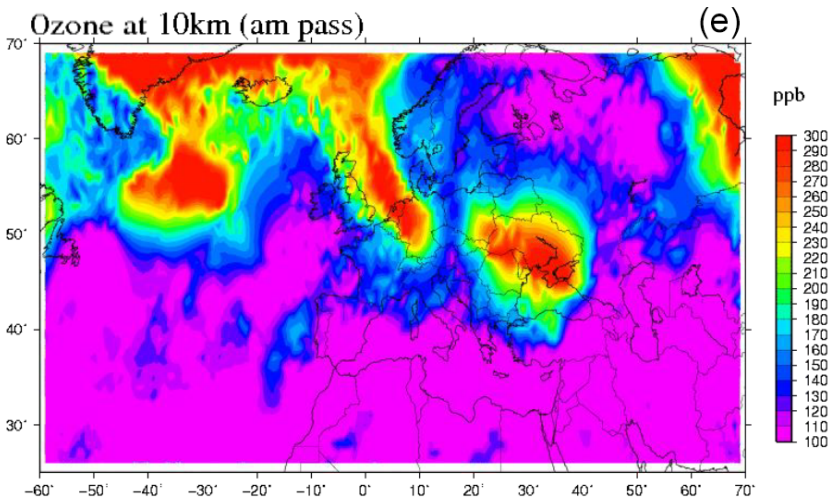

IASI+GOME2/MetOp 20110702-20110703

IASI+GOME2/MetOp

(c)
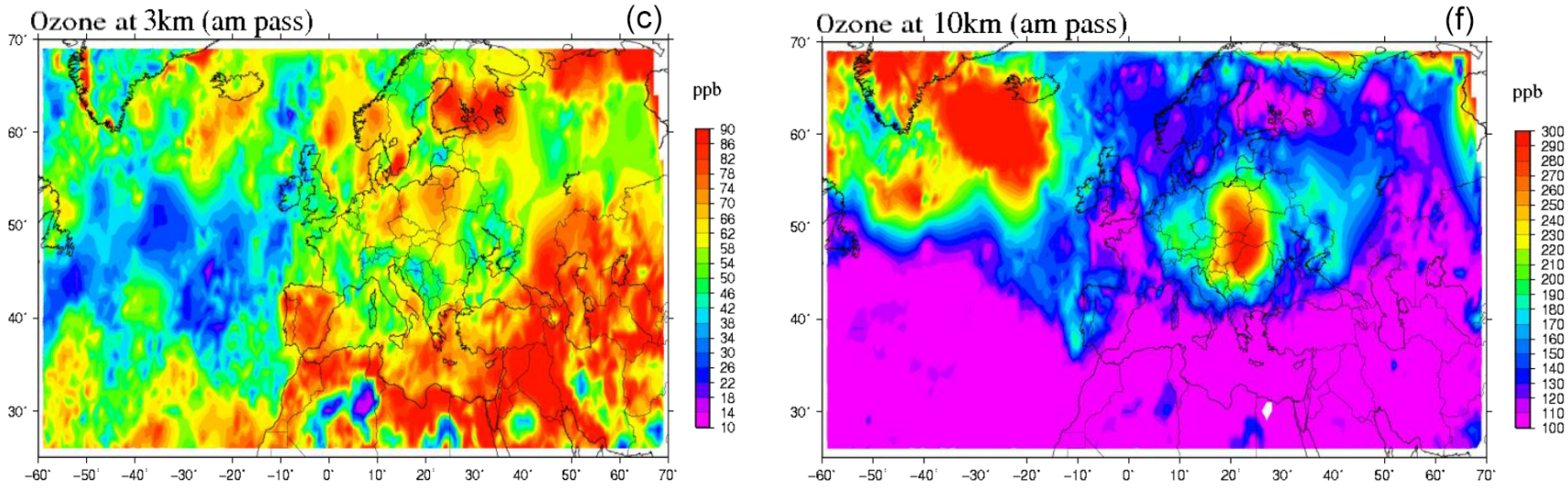

Figure 11. IASI + GOME-2 satellite images of ozone concentration at $3 \mathrm{~km}(\mathbf{a}, \mathbf{b}, \mathbf{c})$ and $10 \mathrm{~km}(\mathbf{d}, \mathbf{e}, \mathbf{f})$ for the episode of 28 June4 July 2011. Starting from the top: 28 June-4 July, 30 June-1 July and 2 July-3 July. 

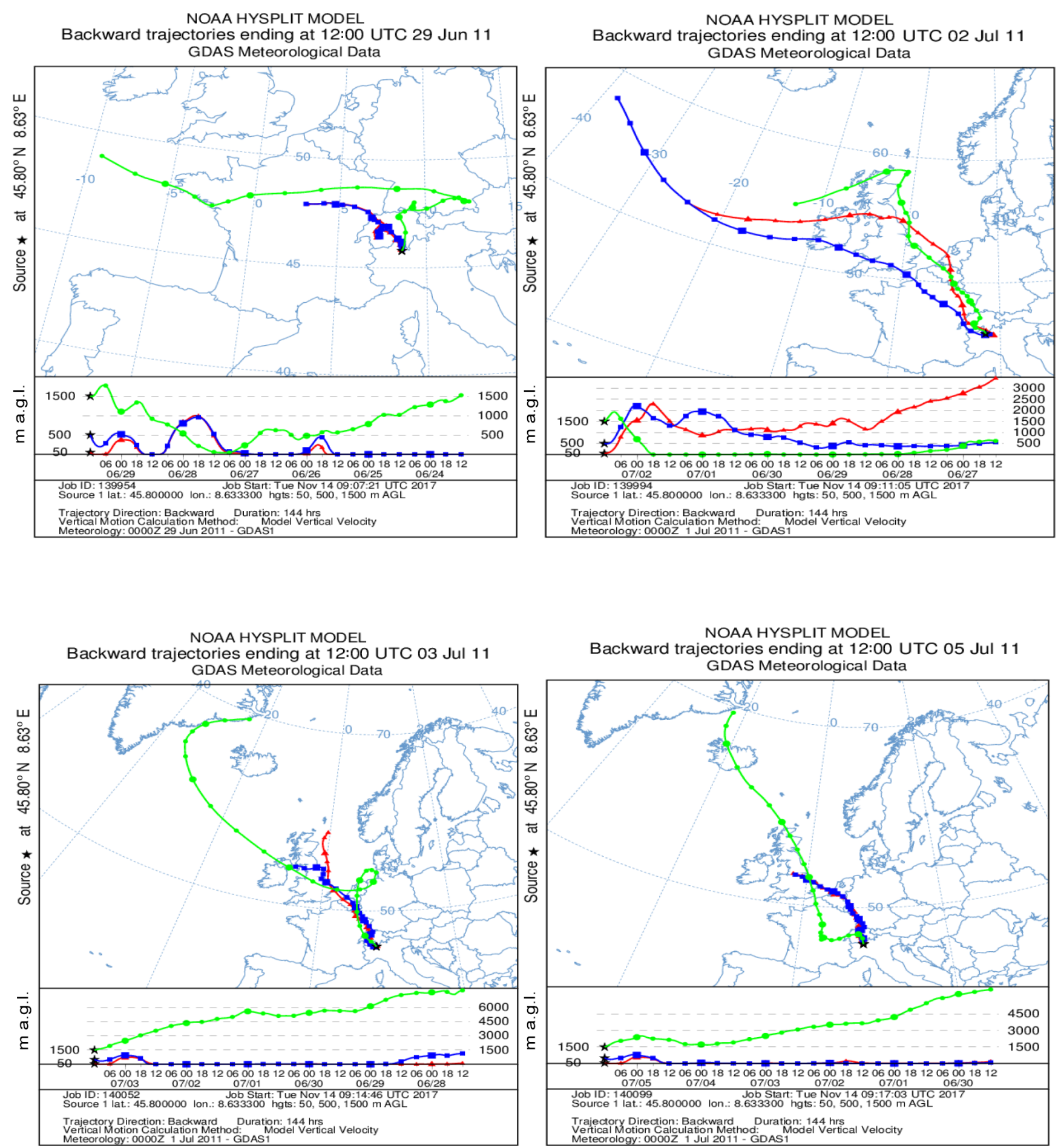

Figure 12. The $6 \mathrm{~d}$ HYSPLIT back trajectories arriving at the JRC Ispra station during the episode of 28 June-4 July 2011.

ular linked with large-scale subsidence were examined. This study is focused on a more detailed analysis of the suggested mechanisms, based on the measurements of ${ }^{7} \mathrm{Be},{ }^{210} \mathrm{~Pb}$ and a very large variety of meteorological and air pollution parameters collected at the JRC Ispra station, which is considered to be one of the most well-equipped measuring sites in Eu- rope. High boundary layer concentrations of ${ }^{7} \mathrm{Be}$ are used as an indicator of the influence of free tropospheric air, in which ${ }^{7} \mathrm{Be}$ activity is high due to a cosmogenic source. ${ }^{210} \mathrm{~Pb}$ activity is an indicator of accumulation of surface emissions and their reaction products and it reaches its highest levels during periods with stagnant air conditions. Radioisotope and 
(a)

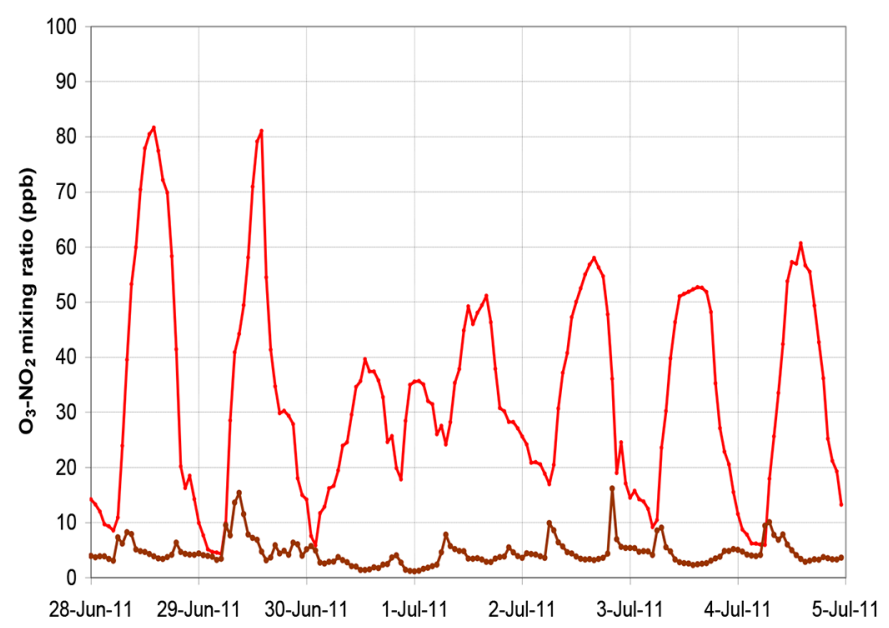

(c)

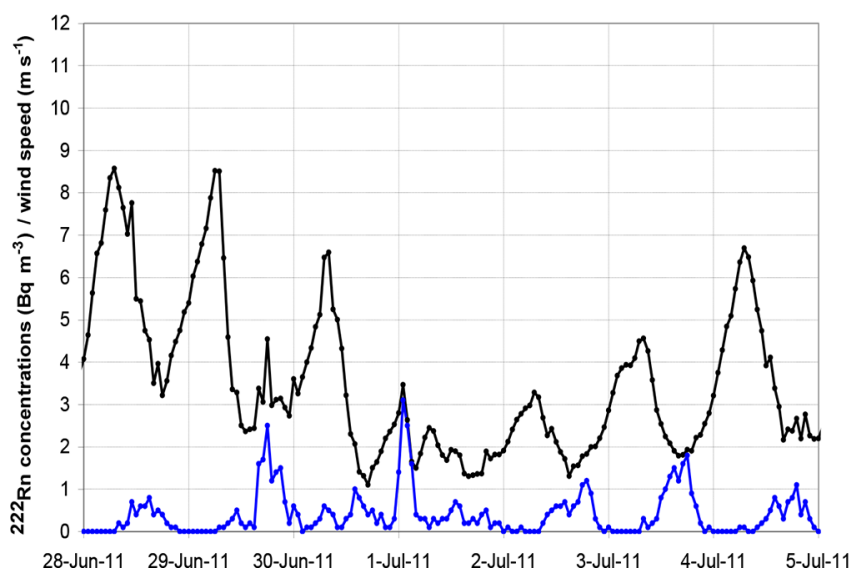

(b)

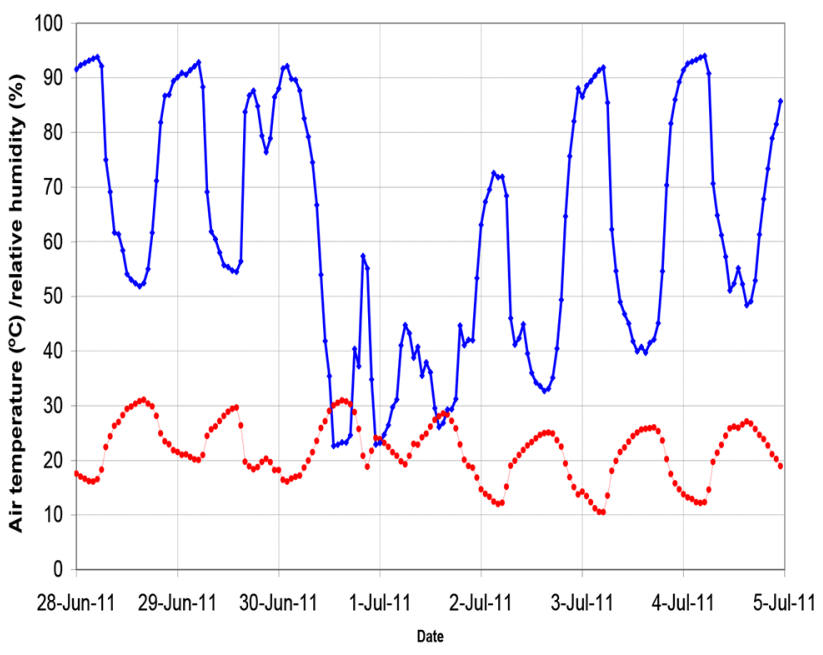

(d)

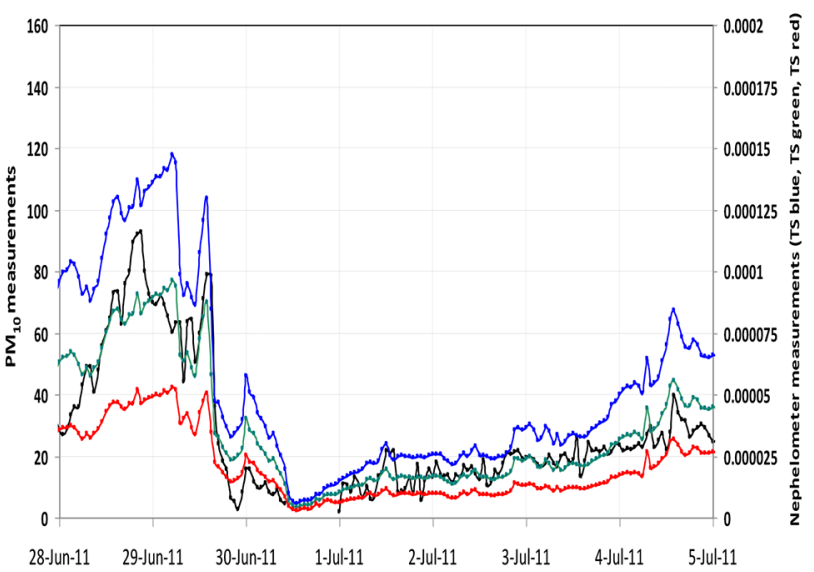

Figure 13. Air pollution and meteorological measurements for 28 June-4 July 2011 at JRC Ispra, Italy. (a) Hourly ozone (red) and nitrogen dioxide (brown) mixing ratios. (b) Hourly relative humidity (blue) and temperature (red) measurements. (c) Hourly ${ }^{222} \mathrm{Rn}$ concentrations

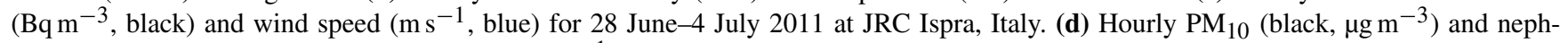
elometer (in blue, green and red) measurements $\left(\mathrm{m}^{-1}\right)$.

humidity data from the Ispra station show that local peaks in ${ }^{7} \mathrm{Be} /{ }^{210} \mathrm{~Pb}$ frequently coincide with local minima in specific humidity, consistent with the hypothesis that these peaks are found in situations with a strong impact of free tropospheric influence on the boundary layer. Comparison with ozone measurements shows that these peaks on some occasions coincide with ozone peaks but more frequently ozone peaks coincide with peaks in ${ }^{7} \mathrm{Be}$ activity. This observation was interpreted as a result of the fact that the highest ozone concentrations are frequently found in situations with a combined impact of entrainment of ozone-rich free tropospheric air and local formation in the boundary layer. The conclusions derived from the analysis of specific episodes were in accordance with this interpretation: the main characteristics of the frequently occurring spring episodes where both ${ }^{7} \mathrm{Be}$ and ozone reach maxima at the Ispra station were found to be the following.

- Anticyclonic stagnant conditions occur over parts of the European continent and the western Mediterranean.

- Strong winds occur at the periphery of the anticyclone associated with a deep low-pressure system located to the north and a weaker one located to the east. A common feature is that Ispra is located at the eastern edge of a ridge system at the $700 \mathrm{hPa}$ level and at the same time a trough is located eastwards. 
- Very extended areas of positive vertical velocity and omega (downward movement) are observed over eastern, central and western Europe, depending on the locations and the relative strength of the high- and lowpressure systems, at all pressure levels and associated with dry conditions (low specific humidity), indicating subsidence.

At the same time, the IASI satellite images show important ozone reservoirs in the upper and lower troposphere, which are generally delimitated by the meteorological systems and follow their movement, while large areas of enhanced tropospheric ozone appear over the region of subsidence, usually originating from the tropospheric ozone reservoirs associated with the low-pressure systems. These results consolidate the findings of the first phase of this study on spring ozone episodes in the western Mediterranean (Kalabokas et al., 2017) and extend them over a full year and a longer time period. The characteristics described above are also encountered during some summer episodes (in June-July) but the conditions generally observed in summer episodes are more related to local photochemical ozone production in the boundary layer while tropospheric subsidence is weaker and more concentrated over the eastern Mediterranean.

The most important new findings of this paper are as follows.

The examination of the Ispra station hourly measurements during subsidence episodes shows that the local pollution parameters (e.g., $\mathrm{NO}_{x},{ }^{222} \mathrm{Rn}$, nephelometer, $\mathrm{PM}_{10}$ ) tend to have low values (compared to those observed during periods of anthropogenic pollution), while the ozone levels usually reach values around 45-60 ppb during the afternoon hours but show significantly higher values than the average during the night and morning hours. This is a clear sign of tropospheric entrainment to the boundary layer.

During high ${ }^{7} \mathrm{Be}$ and high ozone episodes, the highest ozone values exceeding the standards usually occur within the following $2-3 \mathrm{~d}$ after the maximum of regional tropospheric subsidence. The increase in ozone concentrations usually occurs under the influence of favorable meteorological conditions for photochemical ozone production in the boundary layer, which is added to the increased regional background due to tropospheric subsidence and thus occasionally leading to exceedances in ozone air quality standards.

The results of this study might be useful for helping the required improvements in the veracity of global ozone air quality models for which biases have been made evident by several recent studies (Cooper et al., 2014; Parrish et al., 2014; Gaudel et al., 2018; Young et al., 2018). Indeed, these models need to accurately represent complex vertical transport processes affecting the surface ozone budget.
Data availability. The following data sources were used: Table 2: The JRC-station data used in this study are available from the authors upon request (niels.jensen@ec.europa.eu, mauro.roveri@ec.europa.eu) Figures 1 and 13: JRC-station data. Figures 2, 3, 7 and 8: NOAA/ESRL charts, https://www.esrl. noaa.gov/psd/data/composites/day/ (last access: 5 May 2019, NOAA/ESRL, 2019). Figures 4, 5, 9 and 10: IASI satellite data. The IASI satellite data used in this study are available from the authors upon request (maxim.eremenko@lisa.u-pec.fr). Figures 6 and 11: Satellite observations of lowermost tropospheric ozone from the IASI + GOME2 multispectral approach can be provided upon request to Juan Cuesta from the LISA laboratory (juan.cuesta@lisa.upec.fr). From 2017, global IASI+GOME2 ozone retrievals are freely available at the AERIS data center at https://iasi. aeris-data.fr/o3_iago2/ (last access: 3 February 2020, Boonne and Cuesta, 2020). Figure 12: NOAA/Hysplit back-trajectories, http:// ready.arl.noaa.gov/hypub-bin/trajtype.pl?runtype $=$ archive (last access: 5 May 2019, NOAA, 2019).

Supplement. The supplement related to this article is available online at: https://doi.org/10.5194/acp-20-1861-2020-supplement.

Author contributions. PK, NRJ and JH prepared the manuscript with contributions from all co-authors to the manuscript/data evaluation. MR provided ${ }^{7} \mathrm{Be}$ and ${ }^{210} \mathrm{~Pb}$ data. NRJ and JH provided ozone and $\mathrm{NO}_{x}$ data. PK provided synoptic meteorological maps and back trajectories. GF, GD, ME and MB provided the IASI satellite ozone measurements.

Competing interests. The authors declare that they have no conflict of interest.

Acknowledgements. The authors would like to acknowledge the following people: Sebastiao Dos Santos and Jean-Philippe Putaud for meteorological data and aerosol physics data, Giovanni Manca for ${ }^{222} \mathrm{Rn}$ data, and Friedrich Lagler and Jean-Philippe Putaud for the help with the ozone and $\mathrm{NO}_{x}$ data. The authors also acknowledge that a small part of the material in the present paper has been previously presented in Jensen et al. (2017) (Fig. 1). Acknowledgement is also made for the composite weather maps, which were provided by the NOAA/ESRL Physical Sciences Division, Boulder, Colorado, from their website at http://www.cdc.noaa.gov/ (last access: 15 May 2019). The authors also acknowledge the NOAA Air Resources Laboratory (ARL) for the provision of the HYSPLIT transport and dispersion model and/or READY website (http: //www.ready.noaa.gov, last access: 15 May 2019) used in this publication. LISA acknowledges CNES (Centre National des Etudes Spatiales)/TOSCA (Terre Océan Surface Continentale Atmosphère) and PNTS (Programme National de Télédétection Spatiale) for endorsing the development and production of ozone observations from IASI + GOME-2 and IASI.

Review statement. This paper was edited by Evangelos Gerasopoulos and reviewed by two anonymous referees. 


\section{References}

Akritidis, D., Zanis, P., Pytharoulis, I., Mavrakis, A., and Karacostas, T.: A deep stratospheric intrusion event down to the earth's surface of the megacity of Athens, Meteorol. Atmos. Phys., 109, 9-18, 2012.

Akritidis, D., Pozzer, A., Zanis, P., Tyrlis, E., Škerlak, B., Sprenger, M., and Lelieveld, J.: On the role of tropopause folds in summertime tropospheric ozone over the eastern Mediterranean and the Middle East, Atmos. Chem. Phys., 16, 14025-14039, https://doi.org/10.5194/acp-16-14025-2016, 2016.

Arimoto, R., Snow, J. A., Graustein, W. C., Moody, J. L., Ray, B. J., Duce, R. A., Turekian, K. K., and Maring, H. B.: Influences of atmospheric transport pathways on radionuclide activities in aerosol particles from over the North Atlantic, J. Geophys. Res., 104, 301-321, 1999.

Balkanski, Y., Jacob, D. J., Gardner, G. M., Graustein, W., and Turekian, K. K.: Transport and residence times of tropospheric aerosols inferred from a global three-dimensional simulation of ${ }^{210} \mathrm{~Pb}$, J. Geophys. Res., 98, 20573-20586, 1993.

Baskaran, M.: Po-210 and Pb-210 as atmospheric tracers and global atmospheric Pb-210 fallout: a review, J. Environ. Radioact., 102, 500-513, 2011.

Beekmann, M., Ancellet, G., and Megie, G.: Climatology of tropospheric ozone in southern Europe and its relation to potential vorticity, J. Geophys. Res., 99, 12841-12853, 1994.

Bourcier, L., Masson, O., Laj, P., Pichon, J. M., Paulat, P., Freney, E., and Sellegri, K.: Comparative trends and seasonal variation of ${ }^{7} \mathrm{Be},{ }^{210} \mathrm{~Pb}$ and ${ }^{137} \mathrm{Cs}$ at two altitude sites in the central part of France, J. Environ. Radioact., 102, 294-301, 2011.

Boynard, A., Clerbaux, C., Coheur, P.-F., Hurtmans, D., Turquety, S., George, M., Hadji-Lazaro, J., Keim, C., and MeyerArnek, J.: Measurements of total and tropospheric ozone from IASI: comparison with correlative satellite, ground-based and ozonesonde observations, Atmos. Chem. Phys., 9, 6255-6271, https://doi.org/10.5194/acp-9-6255-2009, 2009.

Boonne, $\mathrm{C}$. and Cuesta, J.: $\mathrm{O}_{3}$ vertical profiles from IASI+GOME2 multispectral retrieval, National Centre for Space Studies (CNES), available at: https://iasi.aeris-data.fr/o3_iago2/, last access: 3 February 2020.

Brattich, E., Liu, H., Tositti, L., Considine, D. B., and Crawford, J. H.: Processes controlling the seasonal variations in ${ }^{210} \mathrm{~Pb}$ and ${ }^{7} \mathrm{Be}$ at the Mt. Cimone WMO-GAW global station, Italy: a model analysis, Atmos. Chem. Phys., 17, 1061-1080, https://doi.org/10.5194/acp-17-1061-2017, 2017.

Brost, R. A., Feichter, J., and Heimann, M.: Three-dimensional simulation of ${ }^{7} \mathrm{Be}$ in a global climate model, J. Geophys. Res., 96, 22423-22445, 1991.

Castell, N., Mantilla, E., and Millan, M. M.: Analysis of tropospheric ozone concentration on a Western Mediterranean site: Castellon (Spain), Environ. Monit. Assess., 136, 3-11, https://doi.org/10.1007/s10661-007-9723-1, 2008.

Clarisse, L., R'Honi, Y., Coheur, P.-F., Hurtmans, D., and Clerbaux, C.: Thermal infrared nadir observations of 24 atmospheric gases, Geophys. Res. Lett., 38, L10802, https://doi.org/10.1029/2011GL047271, 2011.

Clerbaux, C., Boynard, A., Clarisse, L., George, M., Hadji-Lazaro, J., Herbin, H., Hurtmans, D., Pommier, M., Razavi, A., Turquety, S., Wespes, C., and Coheur, P.-F.: Monitoring of atmospheric composition using the thermal infrared IASI/MetOp sounder, At- mos. Chem. Phys., 9, 6041-6054, https://doi.org/10.5194/acp-96041-2009, 2009.

Coheur, P.-F., Barret, B., Turquety, S., Hurtmans, D., Hadji-Lazaro, J., and Clerbaux, C.: Retrieval and characterization of ozone vertical profiles from a thermal infrared nadir sounder, J. Geophys. Res., 110, D24303, https://doi.org/10.1029/2005JD005845, 2005.

Coman, A., Foret, G., Beekmann, M., Eremenko, M., Dufour, G., Gaubert, B., Ung, A., Schmechtig, C., Flaud, J.-M., and Bergametti, G.: Assimilation of IASI partial tropospheric columns with an Ensemble Kalman Filter over Europe, Atmos. Chem. Phys., 12, 2513-2532, https://doi.org/10.5194/acp12-2513-2012, 2012.

Cooper, O. R., Oltmans, S. J., Johnson, B. J., Brioude, J., Angevine, W., Trainer, M., Parrish, D. D., Ryerson, T. R., Pollack, I., Cullis, P. D., Ives, M. A., Tarasick, D. W., AlSaadi, J., and Stajner, I.: Measurement of western U.S. baseline ozone from the surface to the tropopause and assessment of downwind impact regions, J. Geophys. Res, 116, D00V03, https://doi.org/10.1029/2011JD016095, 2011.

Cooper, O. R., Gao, R.-S., Tarasick, D., Leblanc, T., and Sweeney, C.: Long-term ozone trends at rural ozone monitoring sites across the United States, 1990-2010, J. Geophys. Res., 117, D22307, https://doi.org/10.1029/2012JD018261, 2012.

Cooper, O. R., Parrish, D. D., Ziemke, J., Balashov, N. V., Cupeiro, M., Galbally, I. E., Gilge, S., Horowitz, L., Jensen, N. R., Lamarque, J.-F., Naik, V. S., Oltmans, J., Schwab, J., Shindell, D. T., Thompson A. M., Thouret, V., Wang, Y., and Zbinden, R. M.: Global distribution and trends of tropospheric ozone: An observation-based review, Elementa, 2, 000029, https://doi.org/10.12952/journal.elementa.000029, 2014.

Cristofanelli, P., Bonasoni, P., Tositti, L., Bonafe, U., Calzolari, F., Evangelisti, F., Sandrini, S., and Stohl, A.: A 6-year analysis of stratospheric intrusions and their influence on ozone at $\mathrm{Mt}$. Cimone (2165 m above sea level), J. Geophys. Res.-Atmos., 111, D03306, https://doi.org/10.1029/2005JD006553, 2006.

Cristofanelli, P., Di Carlo, P., Aruffo, E., Apadula, F., Bencardino, M., D'Amore, F., Bonasoni, P., and Putero, D.: An Assessment of Stratospheric Intrusions in Italian Mountain Regions Using STEFLUX, Atmosphere, 9, 413, https://doi.org/10.3390/atmos9100413., 2018.

Cuevas, E., González, Y., Rodríguez, S., Guerra, J. C., GómezPeláez, A. J., Alonso-Pérez, S., Bustos, J., and Milford, C. Assessment of atmospheric processes driving ozone variations in the subtropical North Atlantic free troposphere, Atmos. Chem. Phys., 13, 1973-1998, https://doi.org/10.5194/acp-131973-2013, 2013.

Cuesta, J., Eremenko, M., Liu, X., Dufour, G., Cai, Z., Höpfner, M., von Clarmann, T., Sellitto, P., Foret, G., Gaubert, B., Beekmann, M., Orphal, J., Chance, K., Spurr, R., and Flaud, J.-M.: Satellite observation of lowermost tropospheric ozone by multispectral synergism of IASI thermal infrared and GOME-2 ultraviolet measurements over Europe, Atmos. Chem. Phys., 13, 9675-9693, https://doi.org/10.5194/acp-13-9675-2013, 2013.

Doche, C., Dufour, G., Foret, G., Eremenko, M., Cuesta, J., Beekmann, M., and Kalabokas, P.: Summertime troposphericozone variability over the Mediterranean basin observed with IASI, Atmos. Chem. Phys., 14, 10589-10600, https://doi.org/10.5194/acp-14-10589-2014, 2014. 
Draxler, R. R. and Rolph, G. D.: HYSPLIT (HYbrid Single-Particle Lagrangian Integrated Trajectory) Model, NOAA Air Resources Laboratory, College Park, MD, available at: http://www.arl.noaa. gov/HYSPLIT.php, NOAA ARL READY Website, last access: 18 December 2015.

Duenas, C., Orza, J. A. G., Cabello, M., Fernandez, M. C., Canete, S., Pérez, M., and Gordo, E.: Air mass origin and its influence on radionuclides activities $\left({ }^{7} \mathrm{Be}\right.$ and ${ }^{210} \mathrm{~Pb}$ ) in aerosol particles at a coastal site in the western Mediterranean, Atmos. Res., 101, 205-214, 2011.

Dufour, G., Eremenko, M., Orphal, J., and Flaud, J.-M.: IASI observations of seasonal and day-to-day variations of tropospheric ozone over three highly populated areas of China: Beijing, Shanghai, and Hong Kong, Atmos. Chem. Phys., 10, 37873801, https://doi.org/10.5194/acp-10-3787-2010, 2010.

Dufour, G., Eremenko, M., Griesfeller, A., Barret, B., LeFlochmoën, E., Clerbaux, C., Hadji-Lazaro, J., Coheur, P.-F., and Hurtmans, D.: Validation of three different scientific ozone products retrieved from IASI spectra using ozonesondes, Atmos. Meas. Tech., 5, 611-630, https://doi.org/10.5194/amt-5611-2012, 2012.

Dufour, G., Eremenko, M., Cuesta, J., Doche, C., Foret, G., Beekmann, M., Cheiney, A., Wang, Y., Cai, Z., Liu, Y., Takigawa, M., Kanaya, Y., and Flaud, J.-M.: Springtime daily variations in lower-tropospheric ozone over east Asia: the role of cyclonic activity and pollution as observed from space with IASI, Atmos. Chem. Phys., 15, 10839-10856, https://doi.org/10.5194/acp-1510839-2015, 2015.

Durana, L., Chudy, M., and Masarik, J.: Investigation of ${ }^{7} \mathrm{Be}$ in the Bratislava atmosphere, J. Radioanal. Nucl. Chem., 207, 345-356, 1996.

Dutkiewicz, V. A. and Husain, L.: Stratospheric and tropospheric components of Be-7 in surface air, J. Geophys. Res.-Atmos., 90, 5783-5788, 1985.

Eremenko, M., Dufour, G., Foret, G., Keim, C., Orphal, J., Beekmann, M., Bergametti, G., and Flaud, J.-M.: Tropospheric ozone distributions over Europe during the heat wave in July 2007 observed from infrared nadir spectra recorded by IASI, Geophys. Res. Lett., 35, L18805, https://doi.org/10.1029/2008GL034803, 2008.

Feely, H. W., Larsen, R. J., and Sanderson, C. G.: Factors that cause seasonal variations in beryllium-7 concentrations in surface air, J. Environ. Radioact., 9, 223-249, 1989.

Feichter, J., Brost, R. A., and Heimann, M.: Three-dimensional modeling of the concentration and deposition of ${ }^{210} \mathrm{~Pb}$ aerosols, J. Geophys. Res., 96, 22447-22469, 1991.

Fishman, J., Wozniak, A. E., and Creilson, J. K.: Global distribution of tropospheric ozone from satellite measurements using the empirically corrected tropospheric ozone residual technique: Identification of the regional aspects of air pollution, Atmos. Chem. Phys., 3, 893-907, https://doi.org/10.5194/acp-3893-2003, 2003.

Foret, G., Hamaoui, L., Schmechtig, C., Eremenko, M., Keim, C., Dufour, G., Boynard, A., Coman, A., Ung, A., and Beekmann, M.: Evaluating the potential of IASI ozone observations to constrain simulated surface ozone concentrations, Atmos. Chem. Phys., 9, 8479-8491, https://doi.org/10.5194/acp-9-8479-2009, 2009.
Forster, P. M., Bodeker, G., Schofield, R., Solomon, S., and Thompson, D.: Effects of ozone cooling in the tropical lower stratosphere and upper troposphere, Geophys. Res. Lett., 34, L23813, https://doi.org/10.1029/2007g1031994, 2007.

Gaggeler, H. W.: Radioactivity in the atmosphere, Radiochem. Acta. 70, 345-353, 1995.

García, P. F., García, M. A. F., and Azahra, M.: ${ }^{7}$ Be behaviour in the atmosphere of the city of Granada January 2005 to December 2009, Atmos. Environ., 47, 84-91, 2012.

Gaudel, A., Cooper, O. R., Ancellet, G., Barret, B., Boynard, A., Burrows, J. P., Clerbaux, C., Coheur, P.-F., Cuesta, J., Cuevas, E., Doniki, S., Dufour, G., Ebojie, F., Foret, G., Garcia, O., Granados Muños, M. J., Hannigan, J. W., Hase, F., Huang, G., Hassler, B., Hurtmans, D., Jaffe, D., Jones, N., Kalabokas, P., Kerridge, B., Kulawik, S. S., Latter, B., Leblanc, T., Le Flochmoën, E., Lin, W., Liu, J., Liu, X., Mahieu, E., McClure-Begley, A., Neu, J. L., Osman, M., Palm, M., Petetin, H., Petropavlovskikh, I., Querel, R., Rahpoe, N., Rozanov, A., Schultz, M.G., Schwab, J., Siddans, R., Smale, D., Steinbacher, M., Tanimoto, H., Tarasick, D. W., Thouret, V., Thompson, A. M., Trickl, T., Weatherhead, E., Wespes, C., Worden, H. M., Vigouroux, C., Xu, X., Zeng, G., and Ziemke, J.: Tropospheric Ozone Assessment Report: Present-day distribution and trends of tropospheric ozone relevant to climate and global atmospheric chemistry model evaluation, Elementa, 6, p. 39, https://doi.org/10.1525/elementa.291, 2018.

George, M., Clerbaux, C., Hurtmans, D., Turquety, S., Coheur, P.F., Pommier, M., Hadji-Lazaro, J., Edwards, D. P., Worden, H., Luo, M., Rinsland, C., and McMillan, W.: Carbon monoxide distributions from the IASI/METOP mission: evaluation with other space-borne remote sensors, Atmos. Chem. Phys., 9, 8317-8330, https://doi.org/10.5194/acp-9-8317-2009, 2009.

Gerasopoulos, E., Zanis, P., Stohl, A., Zerefos, C. S., Papastefanou, C., Ringer, W., Tobler, L., Hübener, S., Gäggeler, H. W., Kanter, H. J., Tositti, L., and Sandrini, S.: A climatology of ${ }^{7} \mathrm{Be}$ at four high-altitude stations at the Alps and the Northern Apennines, Atmos. Environ., 35, 6347-6360, 2001.

Gerasopoulos, E., Kouvarakis, G., Vrekoussis, M., Kanakidou, M., and Mihalopoulos, N.: Ozone variability in the marine boundary layer of the Eastern Mediterranean based on 7-year observations, J. Geophys. Res., 110, D15309, https://doi.org/10.1029/2005JD005991, 2005.

Gerasopoulos, E., Zanis, P., Papastefanou, C., Zerefos, C. S., Ioannidou, A., and Wernli, H.: A complex case study of down to the surface intrusions of persistent stratospheric air over the Eastern Mediterranean, Atmos. Environ., 40, 4113-4125, 2006.

Graustein, W. and Turekian, K. K.: ${ }^{7} \mathrm{Be}$ and ${ }^{210} \mathrm{~Pb}$ indicate an upper troposphere source for elevated ozone in the summertime subtropical free troposphere of the eastern North Atlantic, Geophys. Res. Lett., 23, 539-542, 1996.

Hernández-Ceballos, M. A., Brattich, E., Cinelli, G., Ajtić J., and Djurdjevic, V.: Seasonality of ${ }^{7} \mathrm{Be}$ concentrations in Europe and influence of tropopause height, Tellus B, 68, 29534, https://doi.org/10.3402/tellusb.v68.29534, 2016.

Hollaway, M. J., Arnold, S. R., Challinor, A. J., and Emberson, L. D.: Intercontinental trans-boundary contributions to ozone-induced crop yield losses in the Northern Hemisphere, Biogeosciences, 9, 271-292, https://doi.org/10.5194/bg-9-2712012, 2012. 
Ioannidou, A., Vasileiadis, A., and Melas, D.: Time lag between the tropopause height and ${ }^{7} \mathrm{Be}$ activity concentrations on surface air, J. Environ. Radioact., 129, 80-85, 2014.

ISO 11929:2010: Determination of the characteristic limits (decision threshold, detection limit and limits of the confidence interval) for measurements of ionizing radiation - Fundamentals and application, 2010.

Ito, K., De Leon, S. F., and Lippmann, M.: Associations between ozone and daily mortality - Analysis and meta-analysis, Epidemiology, 16, 446-457, https://doi.org/10.1097/01.ede.0000165821.90114.7f, 2005.

Jaenicke, G.: Atmospheric physics and chemistry in meteorology, edited by: Fischer, R., Physical and Chemical Properties of Air, Laudelt-Boernstein Series, Group V, 4b, Springer, Berlin, 391457, 1988.

Jensen, N. R., Kalabokas, P., Roveri, M., and Hjorth, J.: Investigation of $\mathrm{O}_{3}$ entrainment at a North-Italian monitoring station during the period 2006-2015, WIT Trans. Ecol. Envir., 211, 87-96, 2017.

Jiwen, L., Starovoitova, V. N., and Wells, D. P.: Long-term variations in the surface air ${ }^{7} \mathrm{Be}$ concentration and climatic changes, J. Environ. Radioact., 116, 42-47, 2013.

Kalabokas, P. D., Viras, L. G., Bartzis, J. G., and Repapis, C. C.: Mediterranean rural ozone characteristics around the urban area of Athens, Atmos. Environ., 34, 5199-5208, 2000.

Kalabokas, P. D., Volz-Thomas, A., Brioude, J., Thouret, V., Cammas, J.-P., and Repapis, C. C.: Vertical ozone measurements in the troposphere over the Eastern Mediterranean and comparison with Central Europe, Atmos. Chem. Phys., 7, 3783-3790, https://doi.org/10.5194/acp-7-3783-2007, 2007.

Kalabokas, P. D., Mihalopoulos, N., Ellul, R., Kleanthous, S., and Repapis, C. C.: An investigation of the meteorological and photochemical factors influencing the background rural and marine surface ozone levels in the Central and Eastern Mediterranean, Atmos. Environ., 42, 7894-7906, 2008.

Kalabokas, P. D., Cammas, J.-P., Thouret, V., Volz-Thomas, A., Boulanger, D., and Repapis, C. C.: Examination of the atmospheric conditions associated with high and low summer ozone levels in the lower troposphere over the eastern Mediterranean, Atmos. Chem. Phys., 13, 10339-10352, https://doi.org/10.5194/acp-13-10339-2013, 2013.

Kalabokas, P., Thouret V., Cammas J.-P., Volz-Thomas, A., Boulanger, D., and Repapis, C. C.: The geographical distribution of meteorological parameters associated with high and low summer ozone levels in the lower troposphere and the boundary layer over the eastern Mediterranean (Cairo case), Tellus B, 67, 27853, https://doi.org/10.3402/tellusb.v67.27853, 2015.

Kalabokas, P., Hjorth, J., Foret, G., Dufour, G., Eremenko, M., Siour, G., Cuesta, J., and Beekmann, M.: An investigation on the origin of regional springtime ozone episodes in the western Mediterranean, Atmos. Chem. Phys., 17, 3905-3928, https://doi.org/10.5194/acp-17-3905-2017, 2017.

Kalnay, E., Kanamitsu, M., Kistler, R., Collins, W., Deaven, D., Gandin, L., Iredell, M., Saha, S., White, G., Woolen, J., Zhu, Y., Chelliah, M., Ebisuzaki, W., Higgins, W., Janowiak, J., Mo, K. C., Ropelewski, C., Wang, J., Leetmaa, A., Reynolds, R., Jenne, R., and Joseph, D.: The NCEP/NCAR Reanalysis 40-year Project, B. Am. Meteorol. Soc., 77, 437-471, 1996.
Kentarchos, A. S., Davies, T. D., and Zerefos, C.: A low latitude stratospheric intrusion associated with a cut-off low, Geophys. Res. Lett., 25, 67-70, 1998.

Kouvarakis, G., Tsigaridis, K., Kanakidou, M., and Mihalopoulos, N.: Temporal variations of surface regional background ozone over Crete Island in the southeast Mediterranean, J. Geophys. Res., 105, 4399-4407, 2000.

Koch, D. M., Jacob, D. J., and Graustein, W. C.: Vertical transport of tropospheric aerosols as indicated by ${ }^{7} \mathrm{Be}$ and ${ }^{210} \mathrm{~Pb}$ in a chemical tracer model, J. Geophys. Res., 101, 18651-18666, 1996.

Langford, A. O., Sen, C. J., Alvarez, R. J., Brioude, J., Cooper, O. R., Holloway, J. S., Lind, M. Y., Marchbanksa, R. D., Pierce, R. B., Sandberg, S. P., Weickmann, A. M., and Williams, E. J.: An Overview of the 2013 Las Vegas Ozone Study (LVOS): Impact of stratospheric intrusions and long-range transport on surface air quality, Atmos. Environ., 109, 305-322, 2015.

Lee, H. N., Tositti, L., Zheng, X., and Bonasoni, P.: Analyses and comparisons of variations of ${ }^{7} \mathrm{Be},{ }^{210} \mathrm{~Pb}$ and ${ }^{7} \mathrm{Be} /{ }^{210} \mathrm{~Pb}$ with ozone observations at two Global Atmospheric Watch stations from high mountains, J. Geophys. Res., 112, D05303, https://doi.org/101029/2006JD007421, 2007.

Lelieveld, J., Berresheim, H., Borrmann, S., Crutzen, P. J., Dentener, F. J., Fischer, H., Feichter, J., Flatau, P. J., Heland, J., Holzinger, R., Korrmann, R., Lawrence, M. G., Levin, Z., Markowicz, K. M., Mihalopoulos, N., Minikin, A., Ramanathan, V., de Reus, M., Roelofs, G. J., Scheeren, H. A., Sciare, J., Schlager, H., Schultz, M., Siegmund, P., Steil, B., Stephanou, E. G., Stier, P., Traub, M., Warneke, C., Williams, J., and Ziereis, H.: Global air pollution crossroads over the Mediterranean, Science, 298, 794-799, 2002.

Lelieveld, J.: Air pollution and climate, in: The Physical Geography of the Mediterranean, edited by: Woodward, J. C., Oxford University Press, 599-614, 2009.

Leppanen, A.-P., Pacini, A. A., Usoskin, I. G., Aldahan,A., Echer, E. Evangelista, H., Klemola, S., and Kovaltsov, G. A., Mursula, K., and Possnert, G.: Cosmogenic ${ }^{7} \mathrm{Be}$ in air: a complex mixture of production and transport, J. Atmos. Sol. Terr. Phys., 72, 10361043, 2010.

Li, Q., Jacob, D. J., Logan, J. A., Bey, I., Yantosca, R. M., Liu, H., Martin, R. V., Fiore, A. M., Field, B. D., Dunca, B. N., and Thouret, V.: A tropospheric ozone maximum over the Middle East, Geophys. Res. Lett., 28, 3235-3238, https://doi.org/10.1029/2001GL013134, 2001.

Liu, H., Jacob, D. J., Dibb, J. E., Fiore, A. M., and Yantosca, R. M.: Constraints on the sources of tropospheric ozone from ${ }^{210} \mathrm{~Pb}-{ }^{7} \mathrm{Be}^{-} \mathrm{O}_{3}$ correlations, J. Geophys. Res., 109, D07306, https://doi.org/10.1029/2003JD003988, 2004.

Liu, X., Chance, K. V., Sioris, C. E., Spurr, R. J. D., Kurosu, T. P., Martin, R. V., and Newchurch, M. J.: Ozone profile and tropospheric ozone retrievals from Global Ozone Monitoring Experiment: Algorithm description and validation, J. Geophys. Res., 110, D20307, https://doi.org/10.1029/2005JD006240, 2005.

Liu, J. J., Jones, D. B. A.,Worden, J. R., Noone, D., Parrington, M., and Kar, J.: Analysis of the summertime buildup of tropospheric ozone abundances over the Middle East and North Africa as observed by the Tropospheric Emission Spectrometer instrument, J. Geophys. Res., 114, D05304, https://doi.org/10.1029/2008JD010993, 2009. 
Lozano, R. L., Hernández-Ceballos, M. A., San Miguel, E. G., Adame, J. A., and Bolívar J. P.: Meteorological factors influencing the ${ }^{7} \mathrm{Be}$ and ${ }^{210} \mathrm{~Pb}$ concentrations in surface air from the southwestern Iberian Peninsula, Atmos. Environ., 63, 168-178, 2012.

Masarik, J. and Beer, J.: Simulation of particle fluxes and cosmogenic nuclide production in the Earth's atmosphere, J. Geophys. Res., 104, 12099-12111, 1999.

Millán, M. M., Salvador, R., Mantilla, E., and Kallos, G.: Photooxidant dynamics in the western Mediterranean in summer: Results from European research projects, J. Geophys. Res., 102, 88118823, https://doi.org/10.1029/96JD03610, 1997.

Millán, M. M., Mantilla, E., Salvador, R., Carratalá, R., Sanz, M. J., Alonso, L., Gangioti, G., and Navazo, M.: Ozone cycles in the western Mediterranean basin: Interpretation of monitoring data in complex coastal terrain, J. Appl. Meteorol., 39, 487-508, 2000.

Mira-Salama, D., Van Dingenen, R., Gruening, C., Putaud, J.-P., Cavalli, F., Cavalli, P., Erdmann, N., Dell'Acqua, A., Dos Santos, S., Hjorth, J., Raes, F., and Jensen, N. R.: Using Föhn conditions to characterize urban and regional sources of particles, Atmos. Res., 90, 159-169, 2008.

Monks, P. S.: A review of the observations and origins of the spring ozone maximum, Atmos. Environ., 34, 3545-3561, 2000.

Monks, P. S., Archibald, A. T., Colette, A., Cooper, O., Coyle, M., Derwent, R., Fowler, D., Granier, C., Law, K. S., Mills, G. E., Stevenson, D. S., Tarasova, O., Thouret, V., von Schneidemesser, E., Sommariva, R., Wild, O., and Williams, M. L.: Tropospheric ozone and its precursors from the urban to the global scale from air quality to short-lived climate forcer, Atmos. Chem. Phys., 15, 8889-8973, https://doi.org/10.5194/acp-15-8889-2015, 2015.

NOAA/ESRL: NOAA/ESRL charts, National Oceanic and Atmospheric Administration, Earth System Research Laboratory, available at: https://www.esrl.noaa.gov/psd/data/composites/ day/, last access: 5 May 2019.

NOAA: HYSPLIT Trajectory Model, National Oceanic and Atmospheric Administration, available at: https://www.esrl.noaa.gov/ psd/data/composites/day/, last access: 5 May 2019.

O'Brien, K.: Secular variations in the production of cosmogenic isotopes in the Earth's atmosphere, J. Geophys. Res., 84, 423-431, 1979.

Papastefanou, C. and Ioannidou, A.: Aerodynamic size association of ${ }^{7} \mathrm{Be}$ in ambient aerosols, J. Environ. Radioact., 26, 273-283, 1995.

Papastefanou, C.: Chapter 11 - Radioactive Aerosol Analysis in Handbook of Radioactivity Analysis (Third Edition), edited by: L'Annunziata, M. F., Elsevier, 727-767, 2012.

Parrish, D. D., Law, K. S., Staehelin, J., Derwent, R., Cooper, O. R., Tanimoto, H., Volz-Thomas, A., Gilge, S., Scheel, H.-E., Steinbacher, M., and Chan, E.: Lower tropospheric ozone at northern mid-latitudes: Changing seasonal cycle, Geophys. Res. Lett., 40, 1631-1636, https://doi.org/10.1002/grl.50303, 2013.

Parrish, D. D., Lamarque, J.-F., Naik, V., Horowitz, L., Shindell, D. T., Staehelin, J., Derwent, R., Cooper, O. R., Tanimoto, H., Volz-Thomas, A., Gilge, S., Scheel, H.-E., Steinbacher, M., and Fröhlich, M.: Long-term changes in lower tropospheric baseline ozone concentrations: Comparing chemistry-climate models and observations at northern midlatitudes, J. Geophys. Res.-Atmos., 119, 5719-5736, https://doi.org/10.1002/2013JD021435, 2014.
Pham, M. K., Betti, M., Nies, H., and Povinec, P. P.: Temporal changes of ${ }^{7} \mathrm{Be},{ }^{137} \mathrm{Cs}$ and ${ }^{210} \mathrm{~Pb}$ activity concentrations in surface air at Monaco and their correlation with meteorological parameters, J. Environ. Radioact., 102, 1045-1054, 2011.

Putaud, J. P., Bergamaschi, P., Cavalli, F., Dell'Acqua, A., Douglas, K., Duerr, M., Fumagalli, I., Goded, I., Grassi, F., Gruening, C., Jensen, N. R., Lagler, F., Manca, G., Dos Santos, Martins, S., Matteucci, M., Passarella, R., Pedroni, V., Pokorska, O., and Roux, D.: JRC-Ispra Atmosphere - Biosphere Climate Integrated monitoring Station: 2015 report; EUR 28513 EN; https://doi.org/10.2760/409157, 2017.

Reiter, R., Munzert, K., Kanter, H. J., and Potzl, K.: Cosmogenic radionuclides and ozone at a mountain station at $3.0 \mathrm{~km}$ a.s.1, Archiv fur Meteorologie, Geophysik und Bioclimatologie, Serie B, 32, 131-160, 1983.

Richards, N. A. D., Arnold, S. R., Chipperfield, M. P., Miles, G., Rap, A., Siddans, R., Monks, S. A., and Hollaway, M. J.: The Mediterranean summertime ozone maximum: global emission sensitivities and radiative impacts, Atmos. Chem. Phys., 13, 2331-2345, https://doi.org/10.5194/acp-13-2331-2013, 2013.

Rodwell, M. J. and Hoskins, B. J.: Monsoons and the dynamics of deserts, Q. J. Roy. Meteor. Soc., 122, 1385-1404, https://doi.org/10.1002/qj.49712253408, 1996.

Rodwell, M. J. and Hoskins, B. J.: Subtropical anticyclones and summer monsoons, J. Climate, 14, 3192-3211, 2001.

Safieddine, S., Boynard, A., Coheur, P.-F., Hurtmans, D., Pfister, G., Quennehen, B., Thomas, J. L., Raut, J.-C., Law, K. S., Klimont, Z., Hadji-Lazaro, J., George, M., and Clerbaux, C.: Summertime tropospheric ozone assessment over the Mediterranean region using the thermal infrared IASI/MetOp sounder and the WRF-Chem model, Atmos. Chem. Phys., 14, 1011910131, https://doi.org/10.5194/acp-14-10119-2014, 2014.

Staehelin, J., Thudium, J., Buehler, R., Volz-Thomas, A., and Graber, W.: Trends in surface ozone concentrations at Arosa (Switzerland), Atmos. Environ., 28, 75-87, https://doi.org/10.1016/13522310(94)90024-8, 1994.

Steinmann, P., Zeller, M., Beuret, P., Ferreri, G., and Estier, S.: Cosmogenic ${ }^{7} \mathrm{Be}$ and ${ }^{22} \mathrm{Na}$ in ground level air in Switzerland (19942011), J. Environ. Radioact., 124, 68-73, 2013.

Tyrlis, E., Lelieveld, J., and Steil, B.: The summer circulation in the eastern Mediterranean and the Middle East: influence of the South Asian Monsoon, Clim. Dynam., 40, 1103-1123, https://doi.org/10.1007/s00382-012-1528-4, 2013.

Tyrlis, E., Škerlak, B., Sprenger, M., Wernli, H., Zittis, G., and Lelieveld, J.: On the linkage between the Asian summer monsoon and tropopause fold activity over the eastern Mediterranean and the Middle East, J. Geophys. Res.-Atmos., 119, 3202-3221, https://doi.org/10.1002/2013JD021113, 2014.

Usoskin, I. G. and Kovaltsov G. A.: Production of cosmogenic ${ }^{7} \mathrm{Be}$ isotope in the atmosphere: Full 3-D modeling, J. Geophys. Res. 113, D12107, https://doi.org/10.1029/2007JD009725, 2008.

Van Dingenen, R., Dentener, F. J., Raes, F., Krol, M. C., Emberson, L., and Cofala, J.: The global impact of ozone on agricultural crop yields under current and future air quality legislation, Atmos. Environ., 43, 604-618, https://doi.org/10.1016/j.atmosenv.2008.10.033, 2009.

Velchev, K., Cavalli, F., Hjorth, J., Marmer, E., Vignati, E., Dentener, F., and Raes, F.: Ozone over the Western Mediterranean Sea - results from two years of shipborne measurements, Atmos. 
Chem. Phys., 11, 675-688, https://doi.org/10.5194/acp-11-6752011, 2011.

Villena, G., Bejan, I., Kurtenbach, R., Wiesen, P., and Kleffmann, J.: Interferences of commercial $\mathrm{NO}_{2}$ instruments in the urban atmosphere and in a smog chamber, Atmos. Meas. Tech., 5, 149-159, https://doi.org/10.5194/amt-5-149-2012, 2012.

Volz, A. and Kley, D.: Evaluation of the Montsouris series of ozone measurements made in the 19th-century, Nature, 332, 240-242, https://doi.org/10.1038/332240a0, 1988.

Worden, H. M., Logan, J. A., Worden, J. R., Beer, R., Bowman, K., Clough, S. A., Eldering, A., Fisher, B. M., Gunson, M. R., Herman, R. L., Kulawik, S. S., Lampel, M. C., Luo, M., Megretskaia, I. A., Osterman, G. B., and Shephard, M. W.: Comparisons of Tropospheric Emission Spectrometer (TES) ozone profiles to ozone-sondes: Methods and initial results, J. Geophys. Res., 112, D03309, https://doi.org/10.1029/2006JD007258, 2007.

Young, P. J., Naik, V., Fiore, A. M., Gaudel, A., Guo, J., Lin, M. Y., Neu, J. L., Parrish, D. D., Rieder, H. E., Schnell, J. L., Tilmes, S., Wild, O., Zhang, L., Ziemke, J. R., Brandt, J., Delcloo, A., Doherty, R. M., Geels, C., Hegglin, M. I., Hu, L., Im, U., Kumar, R., Luhar, A., Murray, L., Plummer, D., Rodriguez, J., Saiz-Lopez, A., Schultz, M. G., Woodhouse, M. T., and Zeng, G.: Tropospheric Ozone Assessment Report: Assessment of global-scale model performance for global and regional ozone distributions, variability, and trends, Elem. Sci. Anth., 6, 10, https://doi.org/10.1525/elementa.265, 2018.
WMO-GAW (World Meteorological Organization - Global Atmosphere Watch): 1st International Expert Meeting on Sources and Measurements of Natural Radionuclides Applied to Climate and Air Quality Studies, WMOTD No, 1201, Report No. 155, Global Atmos. Watch, Geneva, Switzerland, 2004.

Zahorowski, W., Chambers, S. D., and Henderson-Sellers, A.: Ground based radon-222 observations and their application to atmospheric studies, J. Environ. Radioact., 76, 3-33, 2004.

Zanis, P., Gerasopoulos, C., Priller, A., Schnabel, C., Zerefos, C., Gäggeler, H. W., Tobler, L., Kubik, P. W., Berger, M., Kanter, H. J., Scheel, H. E., Luterbach, J., and Stohl, A.: An estimate of the impact of stratospheric-to-troposphere transport (STT) on the lower free tropospheric ozone over the Alps using ${ }^{10} \mathrm{Be}$ and ${ }^{7} \mathrm{Be}$ measurements, J. Geophys. Res., 108, 8520, https://doi.org/10.1029/2002JD002604, 2003.

Zanis, P., Hadjinicolaou, P., Pozzer, A., Tyrlis, E., Dafka, S., Mihalopoulos, N., and Lelieveld, J.: Summertime free-tropospheric ozone pool over the eastern Mediterranean/Middle East, Atmos. Chem. Phys., 14, 115-132, https://doi.org/10.5194/acp-14-1152014, 2014.

Zerefos, C. S., Kourtidis, K. A., Melas, D., Balis, D., Zanis, P., Katsaros, L., Mantis, H. T., Re-papis, C., Isaksen, I., Sundet, J., Herman, J., Bhartia, P. K., and Calpini, B.: Photo-chemical Activity and Solar Ultraviolet Radiation (PAUR) Modulation factors: An overview of the project, J. Geophys. Res., 107, 8134, https://doi.org/10.1029/2000JD00134, 2002. 